Necessity and Requirements of a Collaborative Effort to Develop a Large Wind Turbine Blade Test Facility in North America

J. Cotrell, W. Musial, and S. Hughes

Technical Report NREL/TP-500-38044

May 2006

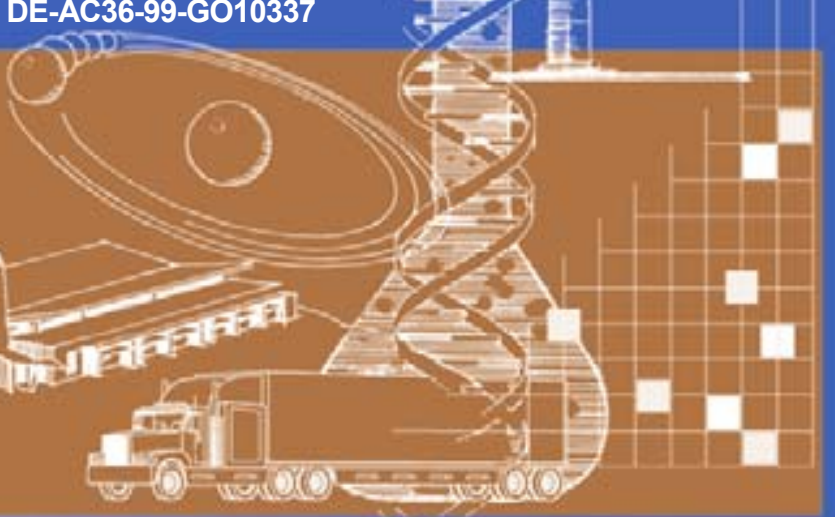




\section{Necessity and Requirements of a Collaborative Effort to Develop a Large Wind Turbine Blade Test Facility in North America}

Technical Report NREL/TP-500-38044

May 2006

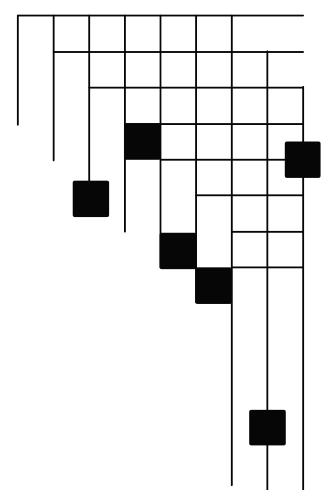




\section{NOTICE}

This report was prepared as an account of work sponsored by an agency of the United States government. Neither the United States government nor any agency thereof, nor any of their employees, makes any warranty, express or implied, or assumes any legal liability or responsibility for the accuracy, completeness, or usefulness of any information, apparatus, product, or process disclosed, or represents that its use would not infringe privately owned rights. Reference herein to any specific commercial product, process, or service by trade name, trademark, manufacturer, or otherwise does not necessarily constitute or imply its endorsement, recommendation, or favoring by the United States government or any agency thereof. The views and opinions of authors expressed herein do not necessarily state or reflect those of the United States government or any agency thereof.

Available electronically at http://www.osti.gov/bridge

Available for a processing fee to U.S. Department of Energy and its contractors, in paper, from:

U.S. Department of Energy

Office of Scientific and Technical Information

P.O. Box 62

Oak Ridge, TN 37831-0062

phone: 865.576 .8401

fax: 865.576 .5728

email: mailto:reports@adonis.osti.gov

Available for sale to the public, in paper, from:

U.S. Department of Commerce

National Technical Information Service

5285 Port Royal Road

Springfield, VA 22161

phone: 800.553 .6847

fax: 703.605.6900

email: orders@ntis.fedworld.gov

online ordering: http://www.ntis.gov/ordering.htm 


\section{Executive Summary}

\section{Introduction}

The wind power industry in North America has an immediate need for larger blade test facilities to ensure the survival of the industry. Blade testing is necessary to meet certification and investor requirements and is critical to achieving the reliability and blade life needed for the wind turbine industry to succeed. The U.S. Department of Energy's (DOE's) Wind Program is exploring options for collaborating with government, private, or academic entities in a partnership to build larger blade test facilities in North America capable of testing blades up to at least $70 \mathrm{~m}$ in length.

The National Renewable Energy Laboratory (NREL) prepared this report for DOE to describe the immediate need to pursue larger blade test facilities in North America, categorize the numerous prospective partners for a North American collaboration, and document the requirements for a North American test facility.

\section{The Problem}

Rapid growth in wind turbine size over the past two decades has outstripped the capacity of blade test facilities at NREL, hindering the North American wind turbine and component manufacturers' opportunities to participate in what is predicted to be more than $\$ 80$ billion of annual global business by 2020. There are significant barriers to North American wind turbine and component manufacturers independently developing their own facilities, including:

- Construction of a blade test facility capable of fatigue testing 70-m blades requires a large initial capital investment of at least $\$ 5$ million to $\$ 11$ million.

- Fatigue testing requires a dedicated staff of at least four people.

- The costs to construct and operate a large blade test facility make the return on investment unattractive for private testing companies.

- The inconsistency of the production tax credit has resulted in an uncertain U.S. market for wind turbines, making the investment in a large facility risky for the wind industry and private testing companies.

- Most North American blade and turbine manufacturers have insufficient testing demand to fully occupy their own, company-specific, large blade test facility, and most other manufacturers would deem it unacceptable to rely on a competitor to provide this service.

- A private facility does not provide third party objectivity required for certification and validation testing.

\section{The Solution}

The preferred solution is for a neutral third party like DOE to facilitate the development of a joint industry collaboration that can provide the needed facilities to all members of the wind industry on a fee-forservice basis. The exact nature of the collaboration may vary, but the objective would be to provide fair access to the needed services. Primary benefits resulting from construction of a large blade test facility are to:

- Directly support the President's Advanced Energy Initiative goal and Departmental priorities of expanding access to wind energy through technology

- Allow wind turbine manufactures to meet certification and investor requirements for wind turbine blades 
- Provide a development path for new products and technologies used in large land-based and offshore wind turbines

- Help understand the failure mechanisms for technologies used to manufacture very large wind turbine blades, thereby reducing the risk and cost of manufacturing, servicing, and warranting large turbines and reducing the cost of electricity from wind turbines

- Maintain the competitiveness of U.S. wind turbine manufacturers with European companies and help ensure U.S. participation in what is predicted to be more than $\$ 80$ billion of annual global business by 2020

- Provide an economic magnet for similar businesses to relocate to a particular region.

Current Program funding levels and the impact of congressionally directed activities at this time require that development of a facility be conducted with significant industry participation and cost share. A number of international, federal, academic, state, municipal, and private entities may be interested in collaborating with DOE on a blade test facility in North America. The primary elements required for a successful blade test facility are land and a building near a seaport, two or more test stands, test equipment, and trained facility staff. DOE may be able to provide some of these items and offer some commitment to testing. NREL, a DOE laboratory operated by the Midwest Research Institute and Battelle, is well-suited to provide the technical expertise and/or staff to develop and operate the facility. Additional funds, inkind services, and testing commitments are required from other collaboration partners for a successful effort. 


\section{Table of Contents}

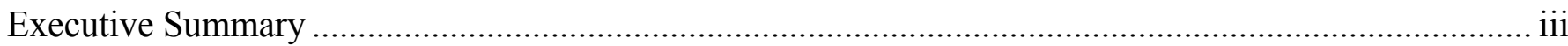

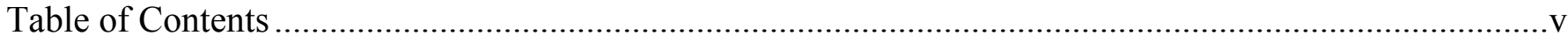

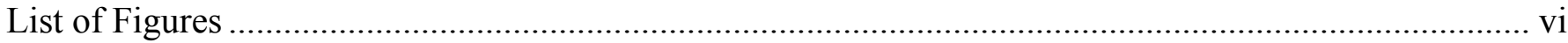

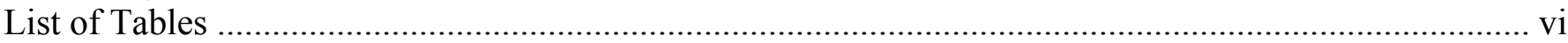

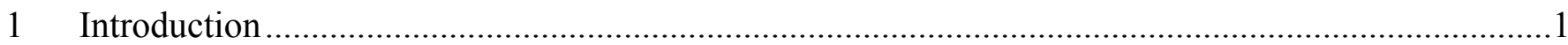

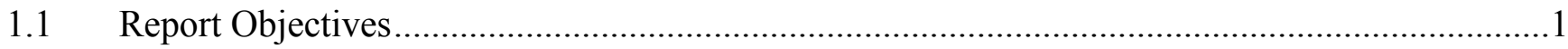

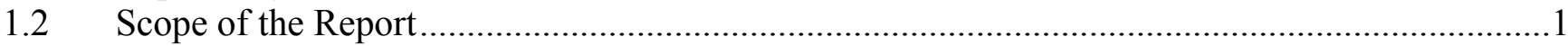

2 Motivations for Pursuing a Large Blade Test Facility Collaboration in North America.........................

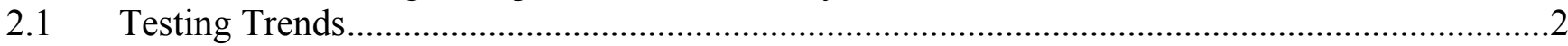

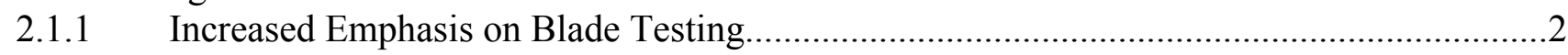

2.1.2 Larger Turbines .......................................................................................................

2.2 North American Industries Have No Large Blade Test Facility Access ......................................

2.2.1 NWTC Blade Test Facility Limitations .......................................................................

2.2.2 Barriers to Construction of New Test Facilities in North America without Government

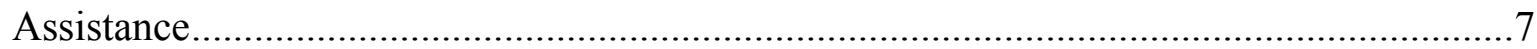

2.2.3 Barriers to Using European Blade Test Facilities ..............................................................

3 Requirements and Costs of a Large Blade Test Facility ...................................................................

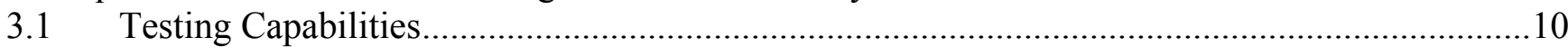

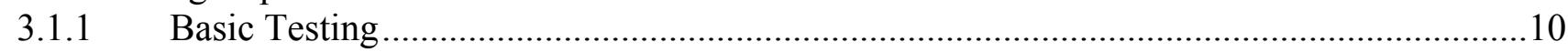

3.1.2 Multiple Test Stands ...............................................................................................11

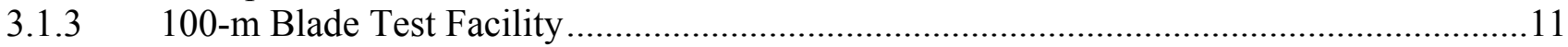

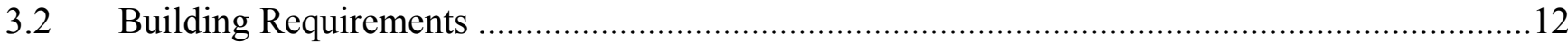

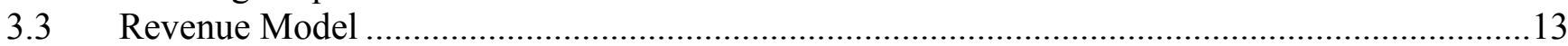

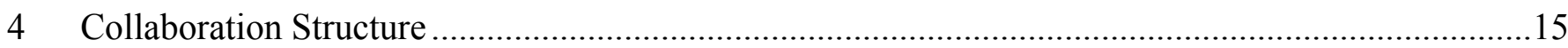

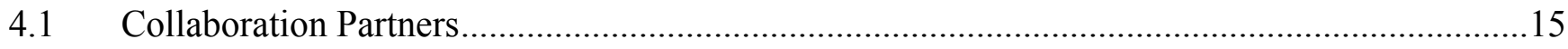

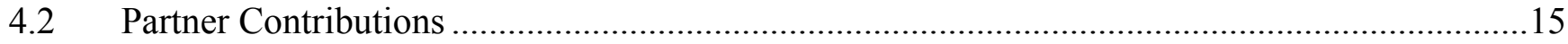

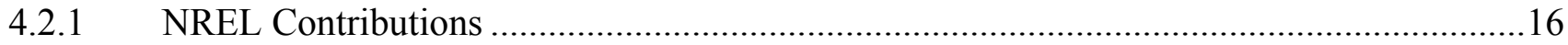

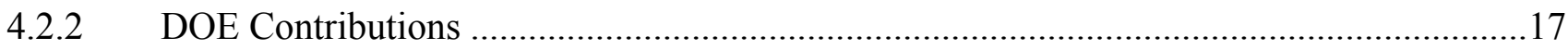

4.2.3 Federal, State, Municipal, or Academic Contributions.....................................................17

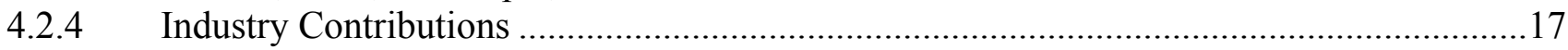

4.3 Ownership and Operating Models for a Collaborative Facility ……………..............................18

4.3.1 Ownership of European Test Facilities ..........................................................................18

4.3.2 Ownership and Operation of a Collaborative Facility in North America .............................18

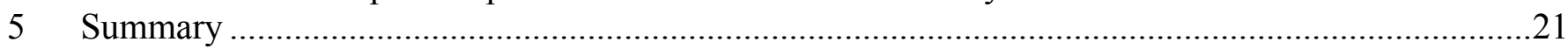

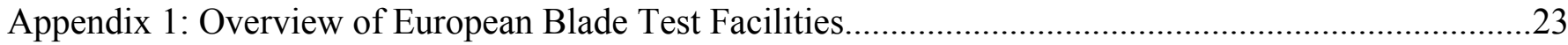

Appendix 2: Detailed Requirements for a Large Blade Test Facility ……..................................................28

Appendix 3: Approximate Costs for Large Blade Test Facility Options ..........................................................30

Appendix 4: Approximate Net Revenue for a Large Blade Test Facility ...................................................31 


\section{List of Figures}

Figure 1: Design lifetime requirements of industries comparable to the wind industry............................

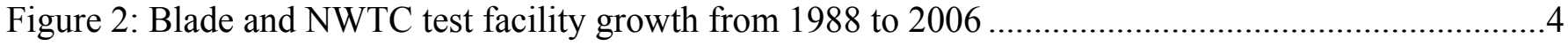

Figure 3: Maximum blade length capacities for blade test facilities worldwide .....................................5

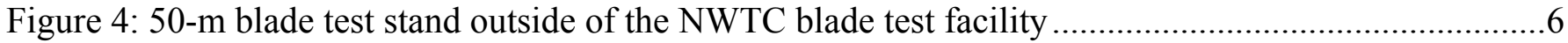

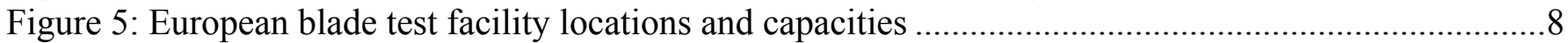

Figure 6: Bell crank system (painted yellow) used in the 34-m NWTC Blade Test Facility for edgewise

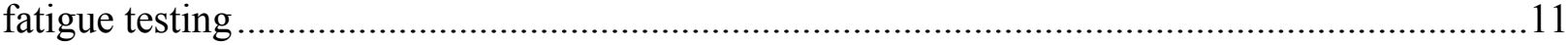

Figure 7: Ultimate strength of the blade root relative to the blade length .........................................12

Figure 8: Installation of the NWTC B-REX fatigue testing system .................................................17

Figure 9: European blade test facility locations and capacities ..................................................23

Figure 10: Maximum blade length capacities for blade test facilities worldwide ................................24

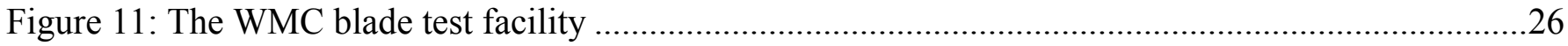

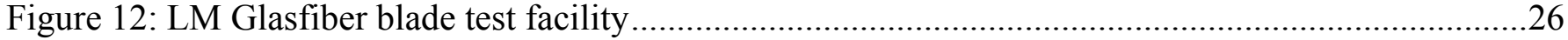

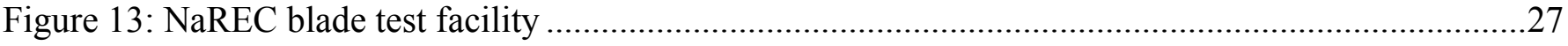

\section{List of Tables}

Table 1: Key Facility Requirements for a Large Blade Test Facility ..................................................

Table 2: Summary of Cost Estimates for a Large Blade Test Facility (\$ in Thousands) ...........................10

Table 3: Approximate Maximum Annual Net Revenue from a Blade Test Facility .................................14

Table 4: Key Requirements for a Blade Test Facility and Possible Contributions of Collaboration

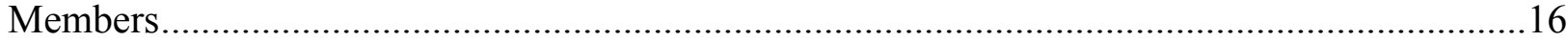

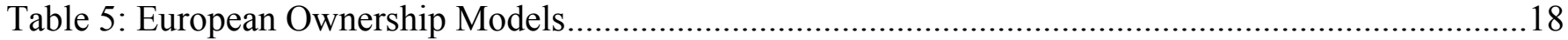

Table 6: Summary of North American Blade Test Facility Collaboration Ownership Models..................19

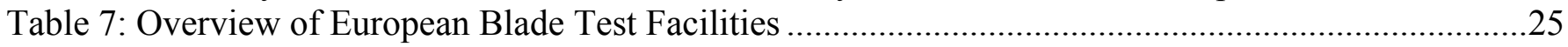

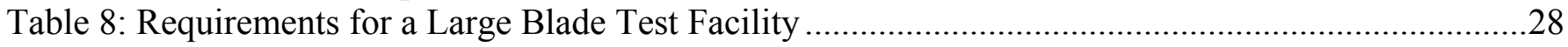

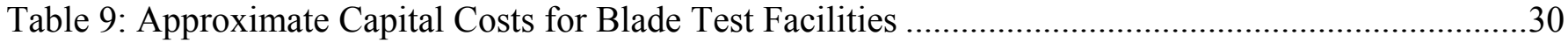

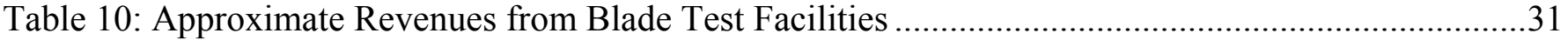




\section{Introduction}

All new designs of large wind turbine blades must be static and fatigue tested to verify their ability to withstand operating loads. The tests reduce financial risk and are necessary to meet certification and investor requirements. The U.S. Department of Energy's (DOE's) National Renewable Energy Laboratory (NREL) operates the only blade test facility in North America capable of performing full-scale testing of megawatt-size wind turbine blades. Recent increases in turbine size have outstripped the capabilities of this blade test facility.

In 2001, the DOE Wind Program began plans to construct an 8-MW dynamometer and 70-m blade test facilities at the National Wind Technology Center (NWTC) to support the Wind Program's public/private partnerships to develop larger turbines. The project passed the first set of DOE facility approvals, but progress stopped before the next step (a conceptual design report) was initiated. The facility was not included in the DOE Office of Energy Efficiency and Renewable Energy's FY06 Budget Request to Congress, and full DOE funding to build larger test facilities is not expected to become available.

The DOE Wind Program is exploring options for collaborating with government, private, or academic entities in a public/private partnership to build larger blade test facilities. The Program's motivation in the collaboration is to provide testing capabilities of sufficient size and availability to support the U.S. wind industry's growth and development, and the deployment of large land-based and offshore wind turbines. This effort directly supports the President's National Energy Policy and Advanced Energy Initiative and Departmental priorities for increasing the viability and deployment of renewable energy.

\subsection{Report Objectives}

The objectives of this strategy paper are to:

1. Summarize and consolidate the DOE Wind Program's efforts and ideas about pursuing a blade test facility collaboration

2. Examine the need for non-private involvement in a collaboration to build larger blade test facilities

3. Explore the size, cost, and technical requirements for a blade test facility necessary to meet North American wind industry needs

4. Examine potential ownership and operational options for a collaborative blade test facility.

\subsection{Scope of the Report}

Collaboration could take many different forms with a variety of partners. The scope of this paper is limited to blade test facilities, one of the wind industry's immediate needs. However, a blade test facility may be part of a larger facility that supports certification and permitting assistance, drivetrain testing, land-based and offshore wind turbine testing, wave energy testing, marine current testing, environmental testing, and acoustic testing. 


\section{Motivations for Pursuing a Large Blade Test Facility Collaboration in North America}

This section examines the motivations for pursuing a large blade test facility in North America. The important points described in this section are summarized below.

- Rapid increases in turbine size have outstripped the capabilities of NREL's blade test facility at the NWTC.

- Full DOE funding to build larger test facilities is not expected to become available in the near future.

- The size of offshore turbines is expected to increase.

- All new wind turbine blade designs must be static and fatigue tested.

- Larger blade test facilities in North America are required to maintain and foster a competitive North American wind industry.

- Blade test facilities capable of fatigue testing are too expensive for most North American wind industry members to construct and operate independently.

- Europe has developed several large blade test facilities, giving European manufacturers a competitive edge.

- Concerns about intellectual property, scheduling priorities, and shipping costs make the North American wind industry's dependence on European test facilities problematic.

- A number of Federal, academic, state, and municipal entities may be willing to participate in a blade test facility collaboration.

\subsection{Testing Trends}

Two primary factors drive the need for larger blade test facilities worldwide: 1) Blades are tested more thoroughly to meet new wind turbine design standards, reduce machine cost, and reduce the financial risk of deploying between hundreds to thousands of a particular wind turbine model; and 2) Turbine size has increased rapidly in the past two decades and will continue to increase as the offshore turbine industry develops.

\subsubsection{Increased Emphasis on Blade Testing}

Wind turbine blades are designed to withstand 20 years of high operating loads. This life is far beyond the service life of any large composite structures subjected to high strains (Figure 1). For this reason, established engineering practices and knowledge from other industries cannot be relied on to validate blade designs. Controlled testing in a blade test facility yields the only reliable validation of individual full-scale designs. 


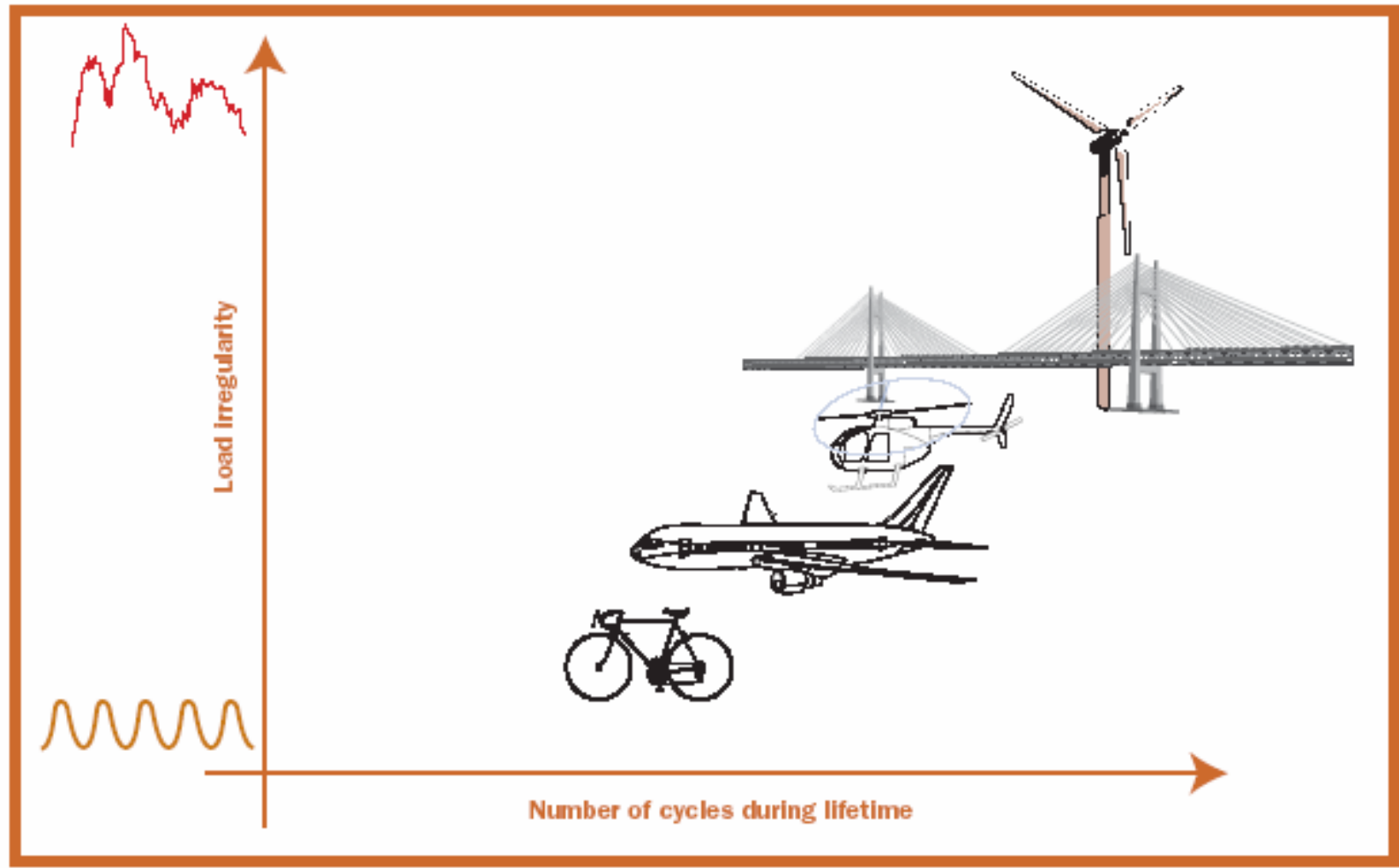

Sarce: WMC (TU Deirt-ECN)

Figure 1: Design lifetime requirements of industries comparable to the wind industry

Blades must be tested more thoroughly to meet new wind turbine design standards, reduce machine cost, and reduce the financial risk of deploying as many as thousands of large wind turbines. U.S.

manufacturers have privately stated that they will not use a blade design without fatigue testing because of the high risk that a potential failure invites. ${ }^{2}$ Moreover, the International Electrotechnical Commission (IEC), the recognized international body for standards development, requires static and modal testing of wind turbine blades for new design or manufacturing process changes and is expected to require fatigue testing by 2009. In addition, the consensus of the IEC full-scale blade test committee members is that the common practice of testing only one article to qualify design and production quality is a bare-minimum requirement. This practice is due primarily to a lack of test facilities and time-to-market requirements. A multiple test stand facility would provide a means to cost effectively conduct multiple tests, thereby greatly increasing the statistical significance and allowing further optimization of design.

\subsubsection{Larger Turbines}

Figure 2 illustrates the rapid growth in wind turbine size over the past two decades. This growth has historically been difficult to predict and has repeatedly exceeded manufacturer predictions. The growth has been driven by factors such as lower balance of station and operations and maintenance costs, access to increased wind speeds at higher elevations, materials and technology improvements, a better understanding of wind turbine loads and design, manufacturing capabilities, and the construction of large offshore machines.

\footnotetext{
${ }^{2}$ U.S. DOE Wind and Hydropower Technologies Program FY2005 DOE Wind Program Strategic Planning Meeting; Washington, D.C.; February 23-24, 2005
} 


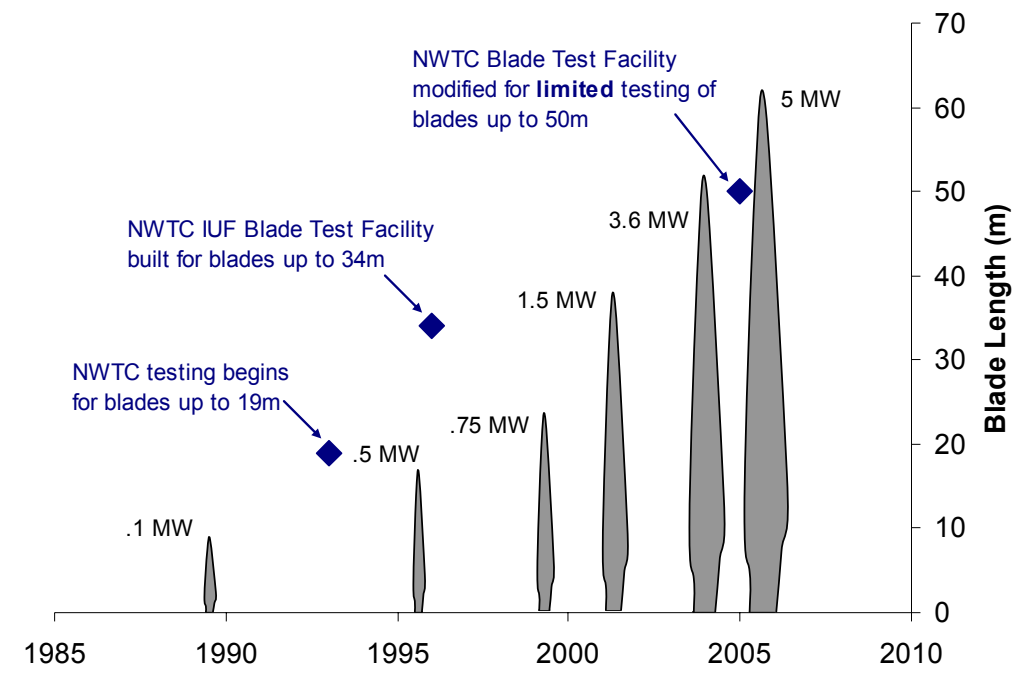

Figure 2: Blade and NWTC test facility growth from 1988 to 2006

The continued development of offshore turbines will motivate the trend to larger machines and will require construction of larger blade test facilities worldwide. More than $800 \mathrm{MW}$ of offshore wind energy capacity operate in shallow waters off the shores of several European countries, and some of these countries plan a major expansion of offshore wind power. The United States has a huge offshore potential (currently estimated to be more than 1000 gigawatts) that provides the opportunity for offshore wind energy to respond to current and future U.S. energy needs. ${ }^{3}$

Presently, the largest offshore machine is rated at $5 \mathrm{MW}$ and uses a $61.5-\mathrm{m}$ blade. Additionally several turbines in the 3.5-MW range, using blades longer than $50 \mathrm{~m}$, are now commercially available. It is widely expected that the turbine size will increase to offset the high cost of offshore foundations and to take advantage of relaxed transportation size constraints offshore. As with land-based turbines, the growth in turbine size will be difficult to predict accurately. Nevertheless, if one extrapolates the exponential growth depicted in Figure 2, offshore machines could conceivably exceed $10 \mathrm{MW}$ in size by 2012 as no technical limits exist to prevent this.

\subsection{North American Industries Have No Large Blade Test Facility Access}

A large blade test facility could serve many North American wind industry members. In addition to enabling larger companies to test blades, smaller companies would also have access to the facility and have the opportunity to develop innovative blade technologies.

\footnotetext{
${ }^{3}$ Wind Energy Program Multi-Year Program Plan 2007-2011 Revision 3.09
} 
Currently, North American wind turbine manufacturers do not have the ability to test blades longer than $50 \mathrm{~m}$ in North America. The lack of facilities in North America puts the North American wind industry at a competitive disadvantage compared to European companies. North American companies will be forced to construct and maintain their own costly test facilities or test in Europe, which is problematic due to concerns about intellectual property (IP), scheduling, shipping, and cost.

This disadvantage could potentially result in a missed opportunity for North American companies to participate in a rapidly growing business. The Global Wind Energy Council estimates that the annual global market for wind turbines could reach $\$ 80$ billion by $2020 .^{4}$ In addition, the lack of facilities jeopardizes the success of programs such as the DOE Low Wind Speed Technology (LWST) and offshore programs to reduce the cost of energy of land-based and offshore machines to levels competitive with fossil fuels.

\subsubsection{NWTC Blade Test Facility Limitations}

The NWTC is limited to testing blades less than $50 \mathrm{~m}$ in length (3 MW) and is small compared to the existing European facilities (Figure 3).

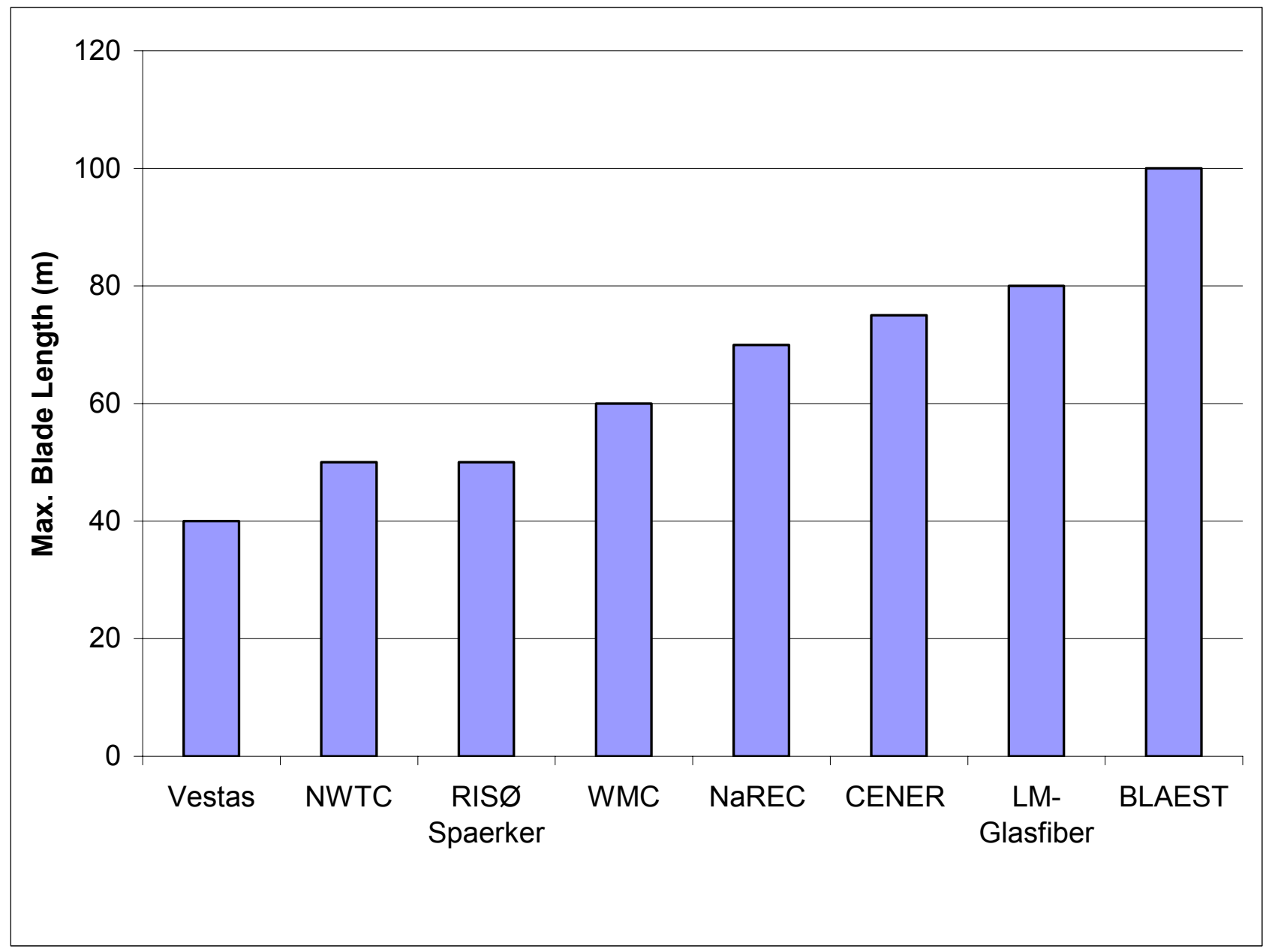

Figure 3: Maximum blade length capacities for blade test facilities worldwide

\footnotetext{
${ }^{4}$ Wind Force 12 http://www.ewea.org/fileadmin/ewea_documents/documents/publications/reports/wf12-2005.pdf
} 
Wind turbines have grown rapidly in size since testing began at the NWTC in 1990. The Industrial User Facility was commissioned in 1997 to test blades up to $34 \mathrm{~m}$. In 2005, a test stand was constructed outside of the facility to allow static and fatigue testing of blades up to $50 \mathrm{~m}$ to bridge the gap to the development of a larger facility. Static testing is conducted outdoors on the inclined face because there is insufficient clearance inside the building. Modal and fatigue testing are conducted indoors using the adjacent, vertical face that allows the blades to extend into the building through a large door (Figure 4).

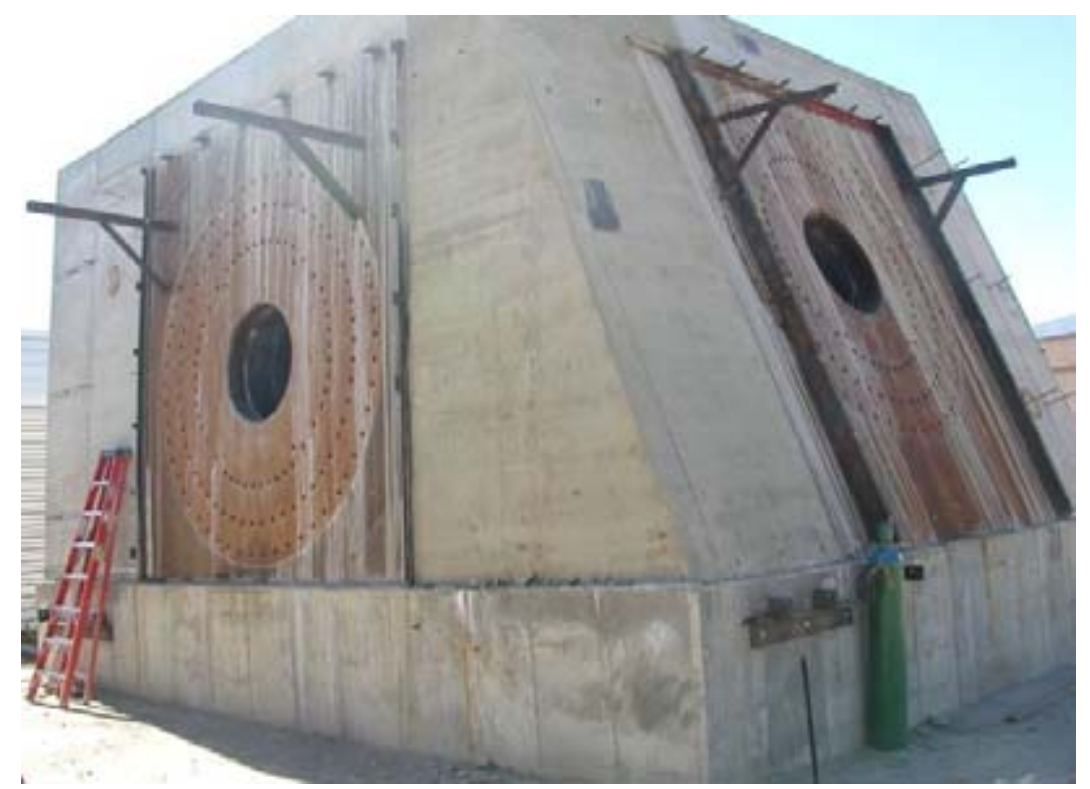

Figure 4: 50-m blade test stand outside of the NWTC blade test facility

In 2001, the Wind Program began plans to construct an 8-MW dynamometer and 70-m blade test facilities at the NWTC to support the growing turbine platforms developed in the LWST Program. The combined cost of the facilities was anticipated to be approximately $\$ 24$ million. According to the DOE Order 413.3, Program and Project Management for the Acquisition of Capital Assets, DOE projects costing more than $\$ 5$ million require four critical decisions before a project proceeds. The first decision, Mission Critical Need Statement (CD-0), was approved in June 2004, but progress stopped before a Conceptual Design Report could be completed because the facility was not included in the DOE Office of Energy Efficiency and Renewable Energy's FY06 Budget Request to Congress. At the time of this writing, there are no plans to pursue test facilities that are fully funded by DOE.

Two additional limitations of the facility are the lack of a blade preparation area and the absence of an additional large test stand. These two limitations dramatically reduce testing throughput and often result in testing backlogs. The lack of a sheltered blade preparation area extends the overall test time by requiring that the blades be installed in the test area for approximately 1 month while strain gauges and other instrumentation are applied. Long lead times, manufacturing complexities, and unexpected delays in manufacturing and testing blades make accommodating the varying schedules of many blade manufacturers difficult with only one test stand and can result in delayed development schedules or insufficient testing.

Other limitations are related to blade movement and positioning. The blade test facility bridge crane can not reach the new 50-m stand. Until this modification is made, relatively expensive mobile cranes must be hired to position the blades on the stand. The NWTC also lacks blade-moving and blade-positioning equipment for blades longer than $34 \mathrm{~m}$. In addition, the NWTC roadways are not sized for movement of blades longer than $34 \mathrm{~m}$. 


\subsubsection{Barriers to Construction of New Test Facilities in North America without Government Assistance}

A common perception exists: The North American wind industry is of sufficient size to provide its own blade testing or attract private testing companies to conduct testing. However, there are several barriers to wind industry members or a private testing company constructing private blade test facilities independent of government assistance. These barriers are summarized here.

Large capital investment - Construction of a blade test facility capable of fatigue testing 70-m blades requires a large initial capital investment of at least $\$ 5$ million to $\$ 11$ million. One primary reason industry has not constructed a large blade test facility is the large capital and operating costs. Some manufacturers can perform static proof load testing on their blades, but fatigue testing is significantly more difficult and expensive. Fatigue testing facilities require a large investment in hydraulic systems and loading devices. The hydraulics, load devices, and instrumentation required for fatigue testing account for roughly $25 \%$ of the cost for a blade test facility and dramatically increase the building size requirements.

Dedicated technical staff required - Fatigue testing requires a dedicated staff of at least four technical experts. In addition to requiring more equipment, fatigue testing is significantly more complex than static testing, and therefore, requires a technical staff dedicated to blade testing. The complexity is inherent in the long test durations, monitoring requirements, and inevitable unexpected events involved with fatigue testing. In addition, fatigue testing technology is still a research area in many respects. New fatigue test methods, loading techniques, data acquisition, and failure theories are being developed. For example, the test engineers and technicians at the NWTC blade test center each have dedicated more than a decade to developing their blade testing skills and knowledge.

Unattractive ROI - The costs to construct and operate a large blade test facility make the return on investment unattractive for private testing companies. Blade preparation, modal, fatigue, and static blade testing require roughly 3 to 4 months of facility time under normal conditions. Most North American blade or turbine manufacturers do not have sufficient revenue or testing demand to justify constructing and staffing a facility capable of fatigue testing large blades. For example, the Danish company LMGlasfiber is one of only a few blade manufacturers in the world that also performs fatigue testing. As a global supplier of blades to many companies, LM is very large relative to U.S. blade companies, with more than $\$ 350$ million in revenue in 2004 and 2,430 employees ${ }^{5}$. In contrast, the largest U.S. blade manufacturer, TPI Composites, reports 300+ employees - many of whom work in the transportation or military divisions ${ }^{6}$.

Unstable U.S. market-The inconsistency of the production tax credit (PTC) has resulted in an uncertain U.S. market for wind turbines that has discouraged long-term investments in the infrastructure. As such, investment in a large blade test facility is considered risky by private companies as the market conditions may change before it could be utilized.

Insufficient testing demand - Most North American blade and turbine manufacturers have insufficient testing demand to fully occupy their own, company-specific, large blade test facility.

\subsubsection{Barriers to Using European Blade Test Facilities}

A number of European large blade test facilities have been constructed in the past 5 years. Figure 5 displays the locations and capacities of these facilities. An overview of these facilities is provided in Appendix 1: Overview of European Blade Test Facilities.

\footnotetext{
${ }^{5}$ LM Glasfiber Holding A/S Financial Highlights: First Half of 2005; http://212.97.129.207/upload/lm fin_2005_q2_uk.pdf

${ }^{6}$ TPI Composites Home Page: About TPI; http://www.tpicomposites.com/index.php?id=1067
} 


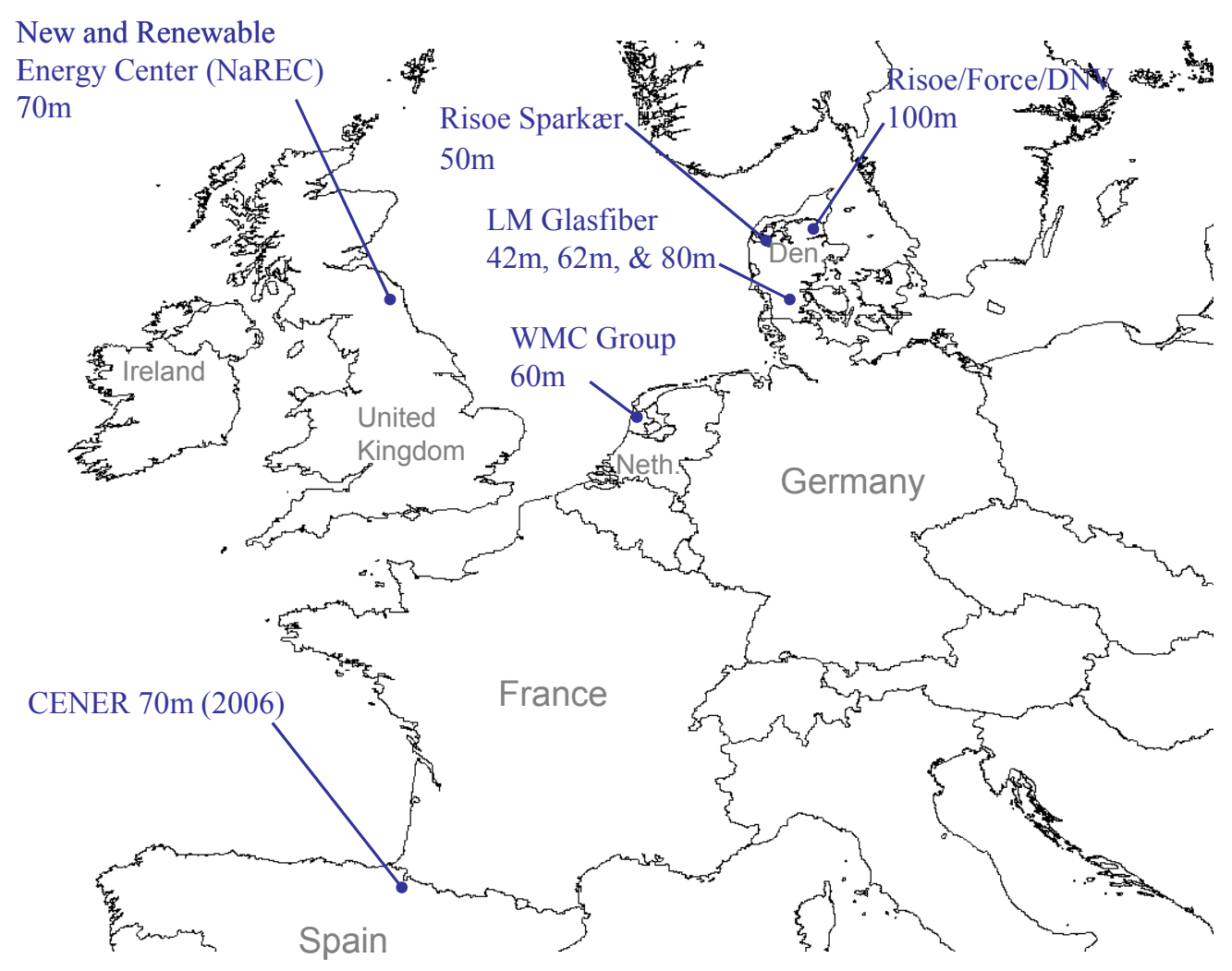

Figure 5: European blade test facility locations and capacities

Although it may be possible for North American companies to use European blade test facilities, concerns about IP, scheduling, and cost make the North American industry's dependence on these facilities problematic.

With the exception of LM Glasfiber, all blade test facilities in Europe are known to have received partial funding by their governments. In general, government-funded European test facilities were built to support the industry of the respective country. Conflicts of interest may arise when scheduling blade tests for North American companies that are potential competitors. In addition, European institutions may be much less flexible in accommodating relatively common requests by companies in North America for special tests or requests to accommodate delays in providing blades for testing.

The cost and delay of shipping blades overseas for testing would be problematic for U.S. companies. The preferred solution, especially for longer blades, is to build the blades in the country in which they will be installed to reduce shipping costs and risk of damage. Although large companies are positioned to compete for access to blade test facilities in Europe, smaller manufacturers may be disadvantaged. In addition, these manufacturers would be forced to send staff on costly and time-consuming foreign travel to supervise testing.

Recent growth of wind turbine manufacturers and increases in financial investments have led to more emphasis on safeguarding intellectual property and protecting company information on development schedules and plans. Innovations in blade construction and airfoil design and protected information about blade failures and product lines are more difficult for North American companies to protect at European institutions than at U.S. facilities; NREL has demonstrated the ability to safeguard protected company information for U.S. companies through nearly two decades of testing experience. 


\section{Requirements and Costs of a Large Blade Test Facility}

Due to the considerable size and forces associated with large blade testing, a blade test facility has a number of unique requirements. These requirements are identified here to facilitate the development of cost estimates and strategies for pursuing a blade test facility. Table 1 and Table 2 summarize the key requirements and costs for a large blade test facility for land-based and offshore turbines. More detailed requirements and cost information are provided in Appendices 2 and 3.

The requirements and costs are rough approximations based on previous experience and vendor quotes. The building costs were obtained using 2005 RSMeans Facilities Construction Data for office and factory floor space. The approximations are site-dependent and are sensitive to factors such as the price of steel and concrete. For this reason, the costs and requirements are intended only to help in strategy formulation. The costs and requirements will continue to be refined as the collaboration and facility plans evolve.

Table 1: Key Facility Requirements for a Large Blade Test Facility

\begin{tabular}{|c|c|c|c|}
\hline Feature & $\begin{array}{l}\text { Single Test } \\
\text { Stand (Basic } \\
\text { Testing) }\end{array}$ & $\begin{array}{c}\text { Multiple Test } \\
\text { Stands } \\
\text { (Sustainable } \\
\text { Financial } \\
\text { Operation) }\end{array}$ & $\begin{array}{l}\text { Additional } \\
\text { Capability for } \\
100-m \\
\text { Capacity }\end{array}$ \\
\hline \multicolumn{4}{|l|}{ Testing capabilities } \\
\hline Total number of test stands & 1 & 2 to 3 & \\
\hline Blade length capacity & $70 \mathrm{~m}(7 \mathrm{MW})$ & $70 \mathrm{~m}(7 \mathrm{MW})$ & $\begin{array}{c}100 \mathrm{~m} \\
(10+\mathrm{MW})\end{array}$ \\
\hline Static load capacity & $50 \mathrm{M} \mathrm{ft-lb}$ & $50 \mathrm{M} \mathrm{ft-lb}$ & $150 \mathrm{M} \mathrm{ft-lb}$ \\
\hline Accredited testing laboratory & $\mathrm{x}$ & $\mathrm{x}$ & \\
\hline Flap twist off-axis static testing & & $\mathrm{x}$ & \\
\hline Resonant fatigue flapwise testing & $\mathrm{x}$ & $\mathrm{x}$ & \\
\hline Resonant edgewise fatigue testing & $\mathrm{x}$ & $\mathrm{x}$ & \\
\hline $\begin{array}{l}\text { Force-displacement fatigue testing (using } \\
\text { bell crank) }\end{array}$ & & $\mathrm{x}$ & \\
\hline $\begin{array}{l}\text { Simultaneous two-axis fatigue testing } \\
\text { (resonant flap testing and force- } \\
\text { displacement edgewise testing) }\end{array}$ & & $x$ & \\
\hline Staffing & 4 & 4 & \\
\hline \multicolumn{4}{|l|}{ Location } \\
\hline Port access & $\mathrm{x}$ & $\mathrm{x}$ & \\
\hline Outdoor storage for blades & $\mathrm{x}$ & $\mathrm{x}$ & \\
\hline \multicolumn{4}{|l|}{ Building } \\
\hline Indoor blade prep area & $\mathrm{x}$ & $\mathrm{x}$ & \\
\hline Total floor space for blade prep and testing & $\begin{array}{l}\text { 100' wide } \\
300 ' \text { long } \\
40^{\prime} \text { tall }\end{array}$ & $\begin{array}{l}\text { 150' to } 200^{\prime} \\
\text { wide } \\
300^{\prime} \text { long } \\
50^{\prime} \text { tall }\end{array}$ & $\begin{array}{l}+75^{\prime} \text { ' wide } \\
+100^{\prime} \text { long } \\
+25^{\prime} \text { tall }\end{array}$ \\
\hline
\end{tabular}


Table 2: Summary of Cost Estimates for a Large Blade Test Facility (\$ in Thousands)

\begin{tabular}{|c|c|c|c|c|}
\hline & Basic Testing & Sustainable Fir & nancial Operation & \\
\hline & $\begin{array}{l}\text { One } 70-m \text { test stand } \\
+ \text { prep area }\end{array}$ & $\begin{array}{l}\text { Two } 70 \text {-m test stands } \\
+ \text { prep area }\end{array}$ & $\begin{array}{l}\text { Three } 70-m \text { test stands } \\
+ \text { prep area }\end{array}$ & $\begin{array}{l}\text { Additional cost to } \\
\text { upgrade one stand to } \\
100 \text {-m capacity }\end{array}$ \\
\hline New Building & 2,100 & 4,422 & 4,422 & 630 \\
\hline $\begin{array}{l}\text { Specialized Building Modifications (test } \\
\text { stand, load attachment points, etc....) }\end{array}$ & 1,350 & 1,875 & 2,400 & 1,250 \\
\hline $\begin{array}{l}\text { Blade Movement \& Positioning } \\
\text { Equipment }\end{array}$ & 410 & 785 & 1,270 & 710 \\
\hline Test Hardware & 440 & 760 & 880 & 230 \\
\hline Hydraulics & 445 & 730 & 1,065 & - \\
\hline Instrumentation & 160 & 272 & 384 & - \\
\hline Total & 4,905 & 8,844 & 10,421 & 2,820 \\
\hline
\end{tabular}

\subsection{Testing Capabilities}

The cost and size of a blade test facility depend primarily on the number of test stands and the blade length capacity. The requirements and costs have been developed for three scenarios (Basic Testing, Multiple Test Stands, and a 100-m Test Facility) to help bracket the number and capacity of the test stands. The scenarios were chosen to span the likely range of facility sizes and are not intended to constrain the development of a business plan.

\subsubsection{Basic Testing}

The Basic Testing scenario represents the minimum facility requirements to ensure adequate blade integrity and meet certification requirements. This scenario represents a low-cost facility, and as such, has several limitations. For example, the facility would not be able to provide a full range of tests, such as force-displacement fatigue testing, two-axis fatigue testing, or off-axis static testing of flap-twist blades. In addition, the facility throughput would be slow, and the facility may not be able to provide enough revenue to cover the operational expenses.

A basic facility would have a single test stand with a blade length capacity of $70 \mathrm{~m}$ and an enclosed blade preparation area. The test stand shall have an overturning moment capacity of 50 million ft-lbs and can accept deflections to failure for both flap and edge loading. This blade length corresponds roughly to a 7MW machine and will enable testing of all wind turbines in production today. (The largest machine in production is currently the German REpower Systems 5-MW machine, which uses 61.5-m blades ${ }^{7}$.) NWTC experience has shown that the long lead times, manufacturing complexities, and unexpected delays in manufacturing and testing blades make test scheduling challenging with a single test bay and can result in delayed development schedules or insufficient testing. Preparing the measurement instrumentation for each blade test is a time-consuming process requiring a blade preparation area. The facility shall also be located in proximity to a port where transport of long blades can be accommodated.

\footnotetext{
${ }^{7}$ REpower 5M Brochure; www.repower.de/fileadmin/download/produkte/RE_PP_5M_uk.pdf
} 


\subsubsection{Multiple Test Stands}

The multiple test stand scenario represents a larger facility that more effectively accommodates industry members' schedules, generates more income to recover the facility operating and maintenance costs, and reduces risk by increasing the statistical significance with multiple tests and by providing a full range of testing. A financially sustainable facility with fewer scheduling conflicts would require two or three $70-\mathrm{m}$ test stands. In addition, the facility should be capable of simultaneous two-axis (edge-wise and flapwise) fatigue tests, which are more accurate than separate tests ${ }^{8}$ and will increase facility throughput. Present blade testing methods require a $\$ 200,000$ bell crank system (Figure 6) to achieve two-axis testing on a 70 $\mathrm{m}$ test stand.

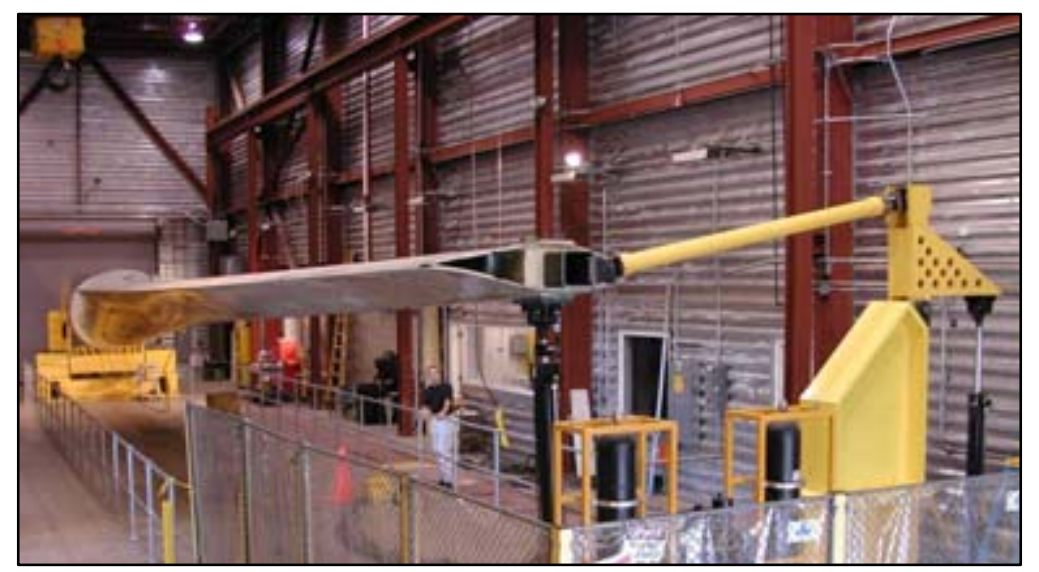

Figure 6: Bell crank system (painted yellow) used in the 34-m NWTC Blade Test Facility for edgewise fatigue testing

The cost of a multiple-test-stand facility is nearly double (roughly $\$ 9 \mathrm{M}$ ) the cost of a basic test facility. From experience, it would be prudent to include expansion capacity into any new test facility to allow for 1) additional test stands to be added, 2) longer blades to be tested, and 3) additional test buildings. Another option would be to construct a building large enough for multiple stands but add equipment as funding allows.

The costs for adding an additional building and test equipment at a later time depend on the building and equipment purchased for the original facility. A rough estimate of these costs is included in Appendix 3. These expansion costs have not been thoroughly explored, but it may be possible to defer roughly $\$ 3$ million in costs for items such as the building, moment foundation, test hardware, hydraulics, and instrumentation. However, expanding the facility at a later date will ultimately result in higher capital costs and some disruption to facility operations.

\subsubsection{0-m Blade Test Facility}

Historically, predictions about wind turbine size increases have underestimated the growth in turbine size. Offshore wind energy is an emerging technology that has tremendous potential in the mid- to long term. Offshore turbine technology could result in a dramatic increase in the size of future wind turbines. Although no wind turbines larger than $6 \mathrm{MW}$ are currently known to be under design, it is possible that facilities larger than $70 \mathrm{~m}$ will be needed in the next 5 years. For these reasons, the 100 -m blade test facility scenario explores the cost to construct a test facility with a 100-m capacity. This scenario is only intended to define the upper limit of feasible possibilities. Construction of expandable facilities and construction of facilities between $70 \mathrm{~m}$ to $100 \mathrm{~m}$ should be further explored.

\footnotetext{
${ }^{8}$ More accurate testing reduces blade uncertainty and cost and may be required by certification agents and investors.
} 
The additional requirements and costs of a replacing a $70-\mathrm{m}$ test stand with a $100-\mathrm{m}$ test stand are listed in the appendix. It is important to note that the foundation strength and blade loads required to test longer blades increase much more quickly than the blade length (Figure 7). Accordingly, a relatively small increase in blade length test capacity translates into a relatively large increase in test facility cost.

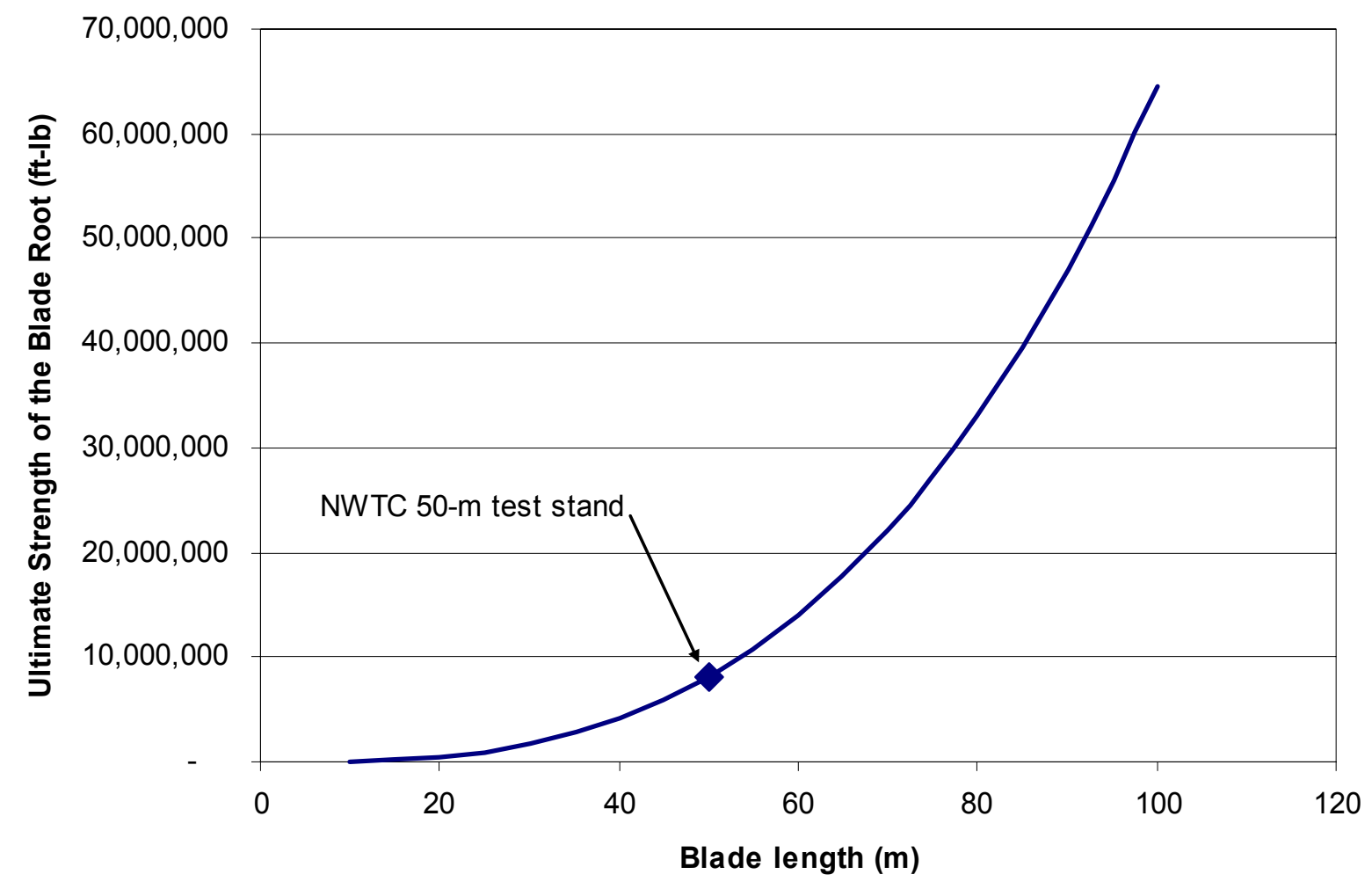

Figure 7: Ultimate strength of the blade root relative to the blade length'

\subsection{Building Requirements}

Construction of a new building represents roughly half the cost of a blade test facility. To reduce cost, it may be possible to find an existing building large enough to accommodate a blade test facility. Roughly 30,000 to $60,000 \mathrm{ft}^{2}$ of unobstructed floor space and at least $40 \mathrm{ft}$ of vertical clearance are required for blade test and blade preparation area (see Table 1 for the building dimensions). If a suitable building is located, it is expected that the floor in the interior of the building will be removed and replaced with a slab to accommodate the test stand and load attachment points.

Office space must also be available in the building or nearby. Several site-dependent improvements (such as road and building access, electrical improvements, etc.) may be required if an existing building is found or if a new building is constructed. The costs for these items included in this report assume a new building is constructed and do not account for any road improvements that may be necessary.

A primary requirement for a large blade test facility is that it has seaport access to accommodate transportation of the large blades. It is anticipated that future offshore blades will be manufactured near ports to overcome land-based length and height transportation restrictions. The location must also provide sufficient outdoor storage area (at least 3 acres) for temporarily storing blades and equipment before and

\footnotetext{
${ }^{9}$ Preliminary Draft of the Final Report for the Large Blade Test Facility Scaling Study; Darris White and Walt Musial, August 9,2004
} 
after testing and for maneuvering heavy equipment. Some possible locations include North American ship-building facilities and ports that need economic revitalization, closed Federal naval bases, and other facilities with coastal access. An in-depth survey of potential sites should be performed.

\subsection{Revenue Model}

A business model demonstrating sufficient revenue to recover operating expenses after the initial capital investment is desirable to reduce partner commitments and ensure the long-term survival of the test facility. To obtain self-sufficiency, the facility must provide enough revenue to operate and maintain the facility and equipment, compensate staff, and make repairs as needed. A crude revenue model has been created as an example and is shown in Table 3. The revenue model assumes that NREL operates the blade test facility. Thus, the overhead and labor-loading rates are consistent with NREL practices. As a government-owned laboratory, there is no insurance cost as the government is self-insured. In addition, the revenue model assumes that the building was purchased and that there is no lease or mortgage.

The revenue of a blade test facility depends on the number and length of blades tested. The revenue generated by a blade test facility can be obtained from compensation for time and materials. Based on NWTC experience and conversations with European blade testing facilities, a full suite of testing on a 1.5MW (34-m) blade requires 3 to 4 months and costs roughly $\$ 300,000$. As a first estimate, the cost of testing longer blades can be assumed to increase linearly with the length of a blade and require an additional month for fatigue testing. Thus, a 70-m blade will generate roughly $\$ 600,000$ in revenue. Based on these assumptions, testing 70-m blades can theoretically result in more annual revenue than 34-m blades.

The number of blades tested in a given year is variable due to factors such as premature failures, manufacturing delays, and demand for new land-based and offshore wind turbine designs. The demand for new designs depends largely on the success of wind turbine markets that are difficult to predict because they are largely dependent on policy factors and fossil energy prices.

Some qualitative comments can be made about the demand to test blades at the new blade test facility. It is not unreasonable to expect that the demand will be about twice the demand experienced by the NWTC blade test facility. The rational for this expectation is based on the idea that, although more land-based turbines are being deployed, the number of new land-based turbine models developed by North American manufacturers will continue at the pace observed over the past 2 years. Additionally, a similar amount of test demand could be created by the involvement of North American manufacturers in the offshore market.

Several scenarios of varying facility throughput were considered for blade test facilities of various sizes. However, because of the difficulty of quantitatively forecasting the demand for the blade test facility, Table 3 presents the results of simplified calculations that assume only $70-\mathrm{m}$ blades are tested and the maximum facility throughput. The supporting calculations are listed in Appendix 4. 
Table 3: Approximate Maximum Annual Net Revenue from a Blade Test Facility

\begin{tabular}{|c|c|c|c|}
\hline & One Test Stand & Two Test Stands & Three Test Stands \\
\hline Number of $70 \mathrm{~m}$ tests per year & 3 & 6 & 9 \\
\hline Annual Revenue & $1,800,000$ & $3,600,000$ & $5,400,000$ \\
\hline Expendable Materials & $(244,398)$ & $(488,796)$ & $(733,194)$ \\
\hline Facilities Fixed Expenses & $(1,403,714)$ & $(1,466,072)$ & $(1,528,430)$ \\
\hline Net Revenue & 151,888 & $1,645,132$ & $3,138,376$ \\
\hline
\end{tabular}

The expendable materials category listed in Table 3 includes electricity for the hydraulic systems, strain gauge materials, and materials for constructing the saddles used to transfer loads to the blade. The fixed expenses category includes items such as staff compensation, facility utilities and maintenance, and capital equipment maintenance and replacement. The largest component of the fixed expenses is the staff salaries (roughly $\$ 750,000$ per year).

Based on the assumptions above, the maximum net revenue from a multiple-test-stand facility is dramatically higher than a single-test-stand facility. The low net revenue from a single-test-stand facility is an indication of the difficulty of creating a sustainable enterprise with only one test stand even when assuming maximum facility throughput. In fact, if the single-blade-test facility tests only two rather than three $70-\mathrm{m}$ blades in a given year, the annual revenue loss is roughly $\$ 900,000$. 


\section{Collaboration Structure}

This section describes some of the potential partners, contributions, ownership options, and operational structures for a North American blade test facility collaboration. The collaboration could take many forms with a variety of partners. This section presents general ideas that would be refined once interested parties are identified.

The scope of this paper is limited to a blade test facility; however, a blade test facility may be part of a larger facility that supports testing of offshore wind turbines, wave energy, and tidal energy technologies. In addition to a blade test facility, the services offered by such a center could include certification and permitting assistance, a drivetrain test facility, land-based and offshore wind turbine testing, wave testing, marine current testing, environmental testing, and acoustic testing.

\subsection{Collaboration Partners}

A number of international, federal, academic, state, municipal, and private entities could be interested in the development of a blade test facility collaboration in North America. Federal agencies, state entities, and municipalities may be interested in fostering renewable energies, stimulating local economic growth, or revitalizing an industrial area. Wind turbine and component manufacturers may be motivated to advance the collaboration in order to test their products and designs. Academic institutions and research laboratories may be motivated by the potential to become involved in research activities and to facilitate professional development of their faculty and staff. The collaboration is also in line with the mission of research laboratories such as NREL. For example, NREL's mission is to develop renewable energy and energy efficiency technologies and practices, advance related science and engineering, and transfer knowledge and innovations to address the nation's energy and environmental goals.

\subsection{Partner Contributions}

The requirements for a blade test facility can be summarized into six key components. Table 4 lists the collaboration members who might be able to contribute these components. 
Table 4: Key Requirements for a Blade Test Facility and Possible Contributions of Collaboration Members

\begin{tabular}{|l|c|c|c|c|c|c|c|}
\hline & Federal & DOE & NREL & $\begin{array}{c}\text { State } \\
\text { Entity }\end{array}$ & $\begin{array}{c}\text { Municipal } \\
\text { Entity }\end{array}$ & $\begin{array}{c}\text { Academic } \\
\text { Institute or } \\
\text { Laboratory }\end{array}$ & $\begin{array}{c}\text { Industry } \\
\text { Partners }\end{array}$ \\
\hline $\begin{array}{l}\text { Land } \\
\text { (near port } \\
\text { facilities) }\end{array}$ & $\mathrm{x}$ & & & $\mathrm{x}$ & $\mathrm{x}$ & $\mathrm{x}$ & \\
\hline Building & $\mathrm{x}$ & $\mathrm{x}$ & & $\mathrm{x}$ & $\mathrm{x}$ & $\mathrm{x}$ & $\mathrm{x}$ \\
\hline Test Stand & $\mathrm{x}$ & $\mathrm{x}$ & & $\mathrm{x}$ & $\mathrm{x}$ & $\mathrm{x}$ & $\mathrm{x}$ \\
\hline $\begin{array}{l}\text { Test } \\
\text { Equipment }\end{array}$ & $\mathrm{x}$ & $\mathrm{x}$ & $\mathrm{x}$ & $\mathrm{x}$ & $\mathrm{x}$ & $\mathrm{x}$ & $\mathrm{x}$ \\
\hline Facility Staff & $\mathrm{x}$ & $\mathrm{x}$ & $\mathrm{x}$ & $\mathrm{x}$ & $\mathrm{x}$ & $\mathrm{x}$ & $\mathrm{x}$ \\
\hline Staff Training & & & $\mathrm{x}$ & & & & $\mathrm{x}$ \\
\hline $\begin{array}{l}\text { Commitments } \\
\text { to Testing }\end{array}$ & & $\mathrm{x}$ & & & & & \\
\hline
\end{tabular}

\subsubsection{NREL Contributions}

NREL's NWTC has the only blade test facility in the United States capable of performing full-scale testing of megawatt-size wind turbine blades. Since 1989, NREL has tested more than 140 blades under fatigue and static loading. This experience will be crucial to establishing new blade test facilities in the United States. NREL could transfer this technology through professional advice, training, or even staff to help operate the facility.

In addition to technical expertise, NREL's NWTC is accredited through the American Association for Laboratory Accreditation (A2LA). A2LA is a signatory to several bilateral and multilateral recognition agreements. These agreements facilitate the acceptance of test and calibration data between A2LAaccredited laboratories and 46 economies around the globe. This accreditation is critical for blade testing to conform to requirements of financial and certification institutions such as Germanischer Lloyd. Significant effort and documentation are required to maintain laboratory accreditation. NREL's experience in maintaining this accreditation could facilitate the accreditation of the new blade test facility.

Another important NREL contribution could be the licensing of the NREL blade resonance excitation system (B-REX) fatigue testing technology (Figure 8). This technology facilitates less expensive fatigue testing that is faster and more accurate. In addition, the technology is being considered for edgewise fatigue testing because force displacement loading with a bell crank may be impractical for blades larger than $50 \mathrm{~m}$ due to the extremely high loads involved. 


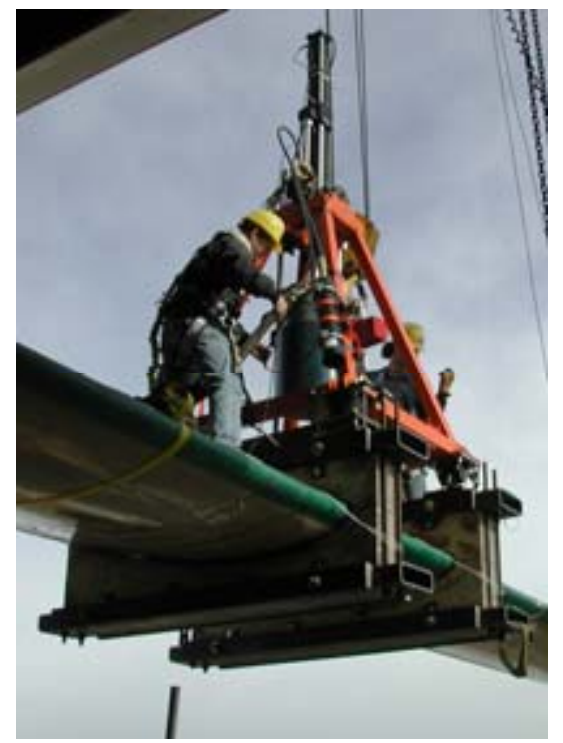

Figure 8: Installation of the NWTC B-REX fatigue testing system

\subsubsection{DOE Contributions}

DOE could make several contributions to a blade test facility collaboration through leadership, funding, and ongoing government support. A crucial DOE contribution could be funding NREL to provide technical support or even staff to the facility. A second possible DOE contribution is to provide funds to purchase or lease a building, test equipment, or other necessary items. However, all program funds are currently committed. In addition, capital projects costing more than $\$ 5$ million require justification through the DOE Critical Decision Process and Congressional approval.

A third DOE role could be as a user to fund tests at the facility through DOE public/private partnerships such as the LWST and Offshore Wind Technology Programs. This commitment, which could take the form of a specific number of blade tests per year, would help sustain the operation of the facility.

\subsubsection{Federal, State, Municipal, or Academic Contributions}

Federal, state, municipal, or academic entities could contribute land, building, funds, facility staff, or other contributions to the project. The costs of the test stand, test hardware, instrumentation, and blade movement equipment comprise approximately one-half of the facility's cost. The building and land comprise the other half of the capital investment. In addition to providing capital funds for the collaboration, federal, state, municipal, or academic entities may have access to or be willing to purchase an existing building or land. Local organizations could provide assistance with zoning and other permitting issues while academic institutions may be able to provide staffing or research assistance support. Local not-for-profit organizations and academic institutions may also be able to provide business oversight, facilities support and receive local development funding.

\subsubsection{Industry Contributions}

Industry partners may be able to make similar contributions as federal, state, municipal, or academic entities. In addition, a key industry partner contribution could be a commitment to testing blades at the facility for a specified number of years. This commitment would reduce the risk of insufficient blade testing revenue for sustainable operation of the facility. 


\subsection{Ownership and Operating Models for a Collaborative Facility}

The numerous prospective partners and the nascent status of the collaboration result in many possible ownership and operating structures for a collaborative blade test facility. The European test facilities provide useful models.

\subsubsection{Ownership of European Test Facilities}

Table 5 summarizes the ownership structures for the blade test facilities in Europe.

Table 5: European Ownership Models

\begin{tabular}{|c|c|c|c|c|c|c|c|c|}
\hline & $\begin{array}{c}\text { RISØ } \\
\text { (Sparkaer) } \\
\end{array}$ & BLAEST & WMC & NaREC & CENER & $\begin{array}{c}\text { LM- } \\
\text { Glasfiber }\end{array}$ & Siemens & Vestas \\
\hline $\begin{array}{l}\text { Government- } \\
\text { owned facility }\end{array}$ & $\mathrm{x}$ & & & & $\mathrm{x}$ & & & \\
\hline $\begin{array}{l}\text { Not-for-profit } \\
\text { enterprise }\end{array}$ & & & $\mathrm{x}$ & $\mathrm{x}$ & & & & \\
\hline $\begin{array}{l}\text { Commercial } \\
\text { consortium }\end{array}$ & & $\mathrm{x}$ & & & & & & \\
\hline $\begin{array}{l}\text { Private } \\
\text { manufacturer } \\
\text { facility }\end{array}$ & & & & & & $\mathrm{x}$ & $\mathrm{x}$ & $\mathrm{x}$ \\
\hline
\end{tabular}

All of the non-private blade test facilities in Europe received some government funding. The facilities in Spain (CENER) and Denmark (Risoe) are government-owned and are operated by a government-funded entity. Two European facilities have joint ownership. The WMC in the Netherlands is a foundation established by the Energy Research Center of the Netherlands (ECN) and Delft University of Technology. The facility was built with government support but relies on commercial work to fund operation.

The new Danish facility (BLAEST) is a joint venture between a government-funded research institute (Risø), a commercial certifying body (Det Norske Veritas or DNV), and an engineering/consulting company (Force Technology). BLAEST now also owns Risø's old test facility in Sparkaer. The shares are divided as follows: $40 \%$ Risø, 35\% Force, and 25\% DNV.

The UK New and Renewable Energy Centre Limited (NaREC) is a self-standing but not-for-profit organization. NaREC is a company limited by guarantee - an alternative type of corporation used primarily for non-profit organizations that require legal personality. A guarantee company does not have share capital, but it has members who are guarantors instead of shareholders. NaREC obtained government funding for its operational core costs. Income will be achieved largely through fees for services, and after 5 years the company will be financially self-sustaining in terms of its operating costs. ${ }^{10}$

\subsubsection{Ownership and Operation of a Collaborative Facility in North America}

The ownership models for a collaborative blade test facility can be categorized by the building and land owner or lessor. Each of these categories can be subdivided by parties that could operate the facility. Table 6 lists four general ownership and operating options for a collaborative blade test facility in North America. Each ownership model is described in the following sections.

\footnotetext{
${ }^{10}$ Renewable Energy for Europe http://europa.eu.int/comm/energy/en/renewable/idae_site/deploy/prj094/prj094_5.html
} 
Table 6: Summary of North American Blade Test Facility Collaboration Ownership Models

\begin{tabular}{|l|l|l|}
\hline $\begin{array}{c}\text { Building/Land } \\
\text { Owner or Lessor }\end{array}$ & \multicolumn{1}{|c|}{$\begin{array}{c}\text { Facility } \\
\text { Operation }\end{array}$} & Comments \\
\hline $\begin{array}{l}\text { DOE } \\
\text { (NREL Extension) }\end{array}$ & MRI-Battelle & $\begin{array}{l}\text { DOE acceptance of donated property is difficult } \\
\text { Donation of DOE property is restricted to non-profit entities } \\
\text { Research overhead and labor rates are high }\end{array}$ \\
\hline $\begin{array}{l}\text { Not-for-profit } \\
\text { enterprise } \\
\text { (state, municipal, or } \\
\text { academic) }\end{array}$ & $\begin{array}{l}\text { Academic } \\
\text { ORI-Battelle } \\
\text { Other organization }\end{array}$ & \\
\hline $\begin{array}{l}\text { Commercial enterprise } \\
\text { (UL) }\end{array}$ & $\begin{array}{l}\text { Commercial entity } \\
\text { MRI-Battelle }\end{array}$ & $\begin{array}{l}\text { Potential problems with the return on capital investment being } \\
\text { sufficient to attract investor interest }\end{array}$ \\
\hline $\begin{array}{l}\text { Wind industry } \\
\text { manufacturer (Clipper, } \\
\text { TPI, GE, NPS ....) }\end{array}$ & $\begin{array}{l}\text { Manufacturer } \\
\text { MRI-Battelle }\end{array}$ & Potential problems with IP protection and schedule conflicts \\
\hline
\end{tabular}

\subsubsection{Facility Owned and Operated by DOE}

NREL and the NWTC are owned by DOE and operated by Midwest Research Institute (MRI) and Battelle. A similar ownership and operating arrangement could be used for the 70-m blade test facility at a location near a seaport. Although current federal budget constraints make full federal funding of the facility unlikely, contributions from collaboration partners could make an extension of the NREL facility feasible at a different location. For example, if collaboration partners could provide a building and funding to construct the test stand, DOE may be able to fund the remaining facility components.

The primary advantage of a facility owned and operated by DOE is that the operation, management, and accreditation procedures for the laboratory could be extended to the new facility. In addition, DOE is an objective owner, and MRI-Battelle have demonstrated outstanding proficiency in operating the NWTC blade test facility.

One potential problem with this arrangement is the difficulty of DOE to assume ownership of donated property or co-own property with another party. The assumption of donated property by DOE is uncommon due in part to the potential liability associated with property acquisitions.

DOE is subject to political decisions. An independent enterprise may be desirable to ensure the survival of the blade test facility. A potential disadvantage of a DOE-owned facility is the restrictions in converting a DOE-owned facility into an independent enterprise. DOE property can be relatively easily transferred to another party if the party is non-profit and is performing research in the interest of DOE.

A disadvantage of an NREL extension is the high labor and overhead rates associated with research institutes such as NREL. Alternatives to the typical laboratory overhead and labor structures should be sought if these rates prohibit sustainable financial operation of the facility.

\subsubsection{Facility Owned by a Not-for-Profit Entity}

This ownership model is similar to the above approach but differs in that a not-for-profit entity (such as a university, state, or municipal organization) would own or lease the building and land. Operation of the facility could be performed by an organization such as a university or by MRI-Battelle as a subcontract or as part of a cooperative research and development agreement (CRADA). 
A CRADA could also be a convenient vehicle for DOE to contribute test equipment, operate the facility, or contract tests with industry through Work for Others agreements. ${ }^{11}$ Alternatively, it may be possible to donate test equipment to the not-for-profit organization.

There are advantages to this approach. It is commonly used in other research settings and follows demonstrated models used to operate European blade test facilities. In addition, the facility is amenable to the formation of a non-profit or commercial enterprise as the limited involvement of DOE lessens some of the property ownership restrictions.

\subsubsection{Facility Owned by One or More Commercial Entities}

This ownership model is similar to the new Danish joint venture (BLAEST) among a government-funded research institute (Risø), a commercial certifying body (DNV), and an engineering/consulting company (Force Technology). Ownership and operation of the facility in this scenario would be by one or more commercial entities. It could also be possible for MRI-Battelle to operate the facility. The objective would be to form a commercial enterprise for profit. One challenge of a facility owned by a commercial entity is establishing a return on investment sufficient to maintain investor interest.

\subsubsection{Facility Owned by a Wind Industry Manufacturer}

A facility operating in this structure would be primarily owned by an industry partner such as a turbine or blade manufacturer. DOE financial or technical support may be possible if the partner allowed tests from other industry members to be performed at the facility. The motivation for DOE's involvement would be to obtain a testing facility that could be made available to the interested industry member and other industry partners. The facility could be operated by the industry member or a third party such as NREL.

The advantage of this approach is that a few private companies currently have the facilities and equipment to move and manipulate large blades. On-site expertise is already available to handle most of the testing and preparatory processes. Existing private companies also have staffing, insurance, and other business processes in place to easily facilitate operation of a new test facility. A cost estimate for such a collaboration is included in Appendix 3. This scenario saves approximately $\$ 600 \mathrm{~K}$ in equipment and nearly $\$ 2$ million in building costs from the Basic Testing Scenario.

There are several fundamental challenges to this collaboration structure. Federal assistance will require the facility to also be available to other industry members. Other industry partners will likely require 1) assurance of IP protection, 2) a facility managed and run by an objective third party such as NREL, and 3) accreditation to be accepted by certification agents and the financial community. These requirements may be difficult to meet if the facility is owned by a single private party.

It may be possible for industry members to collaborate. For example, a blade manufacturer and turbine manufacturer could collaborate in constructing test facilities. If the arrangement were to benefit several industry partners, it may also be possible for DOE and NREL to provide technical support, staffing, or a commitment to testing. However, conflicts of interest among industry partners and proprietary information will create challenges to this arrangement. This paper does not explore options directly between industry partners as they are best qualified to explore these options.

\footnotetext{
${ }^{11}$ NREL Transferring Technologies www.nrel.gov/technologytransfer/partnering.html\#crada
} 


\section{Summary}

The wind power industry in North America has an immediate need for larger blade test facilities to ensure the survival of the industry. Blade testing is necessary to meet certification and investor requirements and is critical to the success of the wind turbine industry. DOE's Wind Program is exploring options for collaborating with government, private, or academic entities in a public/private partnership to build larger blade test facilities in North America capable of testing blades up to at least $70 \mathrm{~m}$ in length. Current Program funding levels and the impact of congressionally directed activities at this time require that any further development of a facility be conducted with significant industry participation and cost share.

\section{Necessity for a Large Blade Test Facility}

- Rapid growth in wind turbine size over the past two decades has outstripped the capacity of blade test facilities in North America, hindering the North American wind turbine and component manufacturers' opportunities to participate in what the Global Wind Energy Council estimates could become an annual global market of $\$ 80$ billion by $2020 .{ }^{12}$

- The North American wind industry has no practical options for testing blades greater than $50 \mathrm{~m}$ in length. The NWTC blade test facility can presently only perform limited testing on blades up to $50 \mathrm{~m}$.

- The use of European large blade test facilities by North American manufacturers is problematic due to concerns about intellectual property, scheduling, and cost.

\section{Primary Benefits of Facility Construction}

- Directly supports the President's Advanced Energy Initiative goal and Departmental priorities of expanding access to wind energy through technology

- Allows wind turbine manufactures to meet certification and investor requirements for wind turbine blades

- Provides a development path for new products and technologies used in large land-based and offshore wind turbines

- Helps understand the failure mechanisms for technologies used to manufacture very large wind turbine blades thereby reducing the risk and cost of manufacturing, servicing, and warranting large turbines thereby reducing the cost of electricity from wind turbines

- Maintains the competitiveness of U.S. wind turbine manufacturers with European companies and helps ensure U.S. participation in what is predicted to be more than $\$ 80$ billion of annual global business by 2020 .

- Provides an economic magnet for similar businesses to relocate to a particular region.

\section{Facility Requirements}

- A primary requirement for a large blade test facility is port access to accommodate transportation of the large dimensions of offshore designs.

- Preliminary cost estimates for a blade test facility (assuming a new building is constructed) are roughly:

- $\$ 5$ million for a basic 70-m single-test-stand test facility without office space or the ability to do a full suite of testing

- \$9 million for a two-test-stand facility with office space and full testing capability (potentially up to $\$ 3$ million of this initial investment could be deferred)

- \$11 million for a three-test-stand facility

- An additional $\$ 3$ million to upgrade a $70-\mathrm{m}$ test stand to a $100-\mathrm{m}$ test stand.

\footnotetext{
${ }^{12}$ Wind Force 12 www.ewea.org/fileadmin/ewea_documents/documents/publications/reports/wf12-2005.pdf
} 
- Construction of a new building represents roughly half of the cost of a blade test facility. To reduce cost, it may be possible to find an existing building large enough to accommodate a blade test facility.

- A self-sustaining business model is desirable to reduce partner commitments and help ensure the long-term survival of the test facility. To obtain self-sufficiency, the facility should provide enough revenue through service fees to operate and maintain the facility.

- A full-service, multiple-test-stand facility will more effectively accommodate industry members' schedules, generate more income to recover the facility operating and maintenance costs, and reduce risk by increasing the statistical significance with multiple tests and by providing a full range of testing.

\section{Collaboration Structure}

- The numerous prospective partners and the nascent status of a North American collaboration result in many possible ownership and operating structures for a collaborative blade test facility. This report categorizes the ownership models into four general options according to the land/building owners or lessors: ownership by 1) DOE, 2) non-profit entities, 3) commercial entities, and 4) wind industry manufacturers.

- Options for operation of the facility include operation by an academic institution, MRI-Battelle, a commercial entity, a manufacturer, or formation of a new entity.

- NREL is well suited to provide technical advice and training, licensing of the B-REX technology, and operation of the facility. Limited DOE funds for construction or equipment and commitments to testing may be possible depending on future budgets. 


\section{Appendix 1: Overview of European Blade Test Facilities}

There are five non-private blade test facilities in Europe (Figure 9 and Table 7), and several manufacturers such as Enercon and LM Glasfiber own private facilities with limited in-house test capabilities. The newer facilities such as BLAEST, WMC (Figure 11), and NaREC (Figure 13) are near ports. Figure 10 provides an overview of the maximum blade length for each facility.

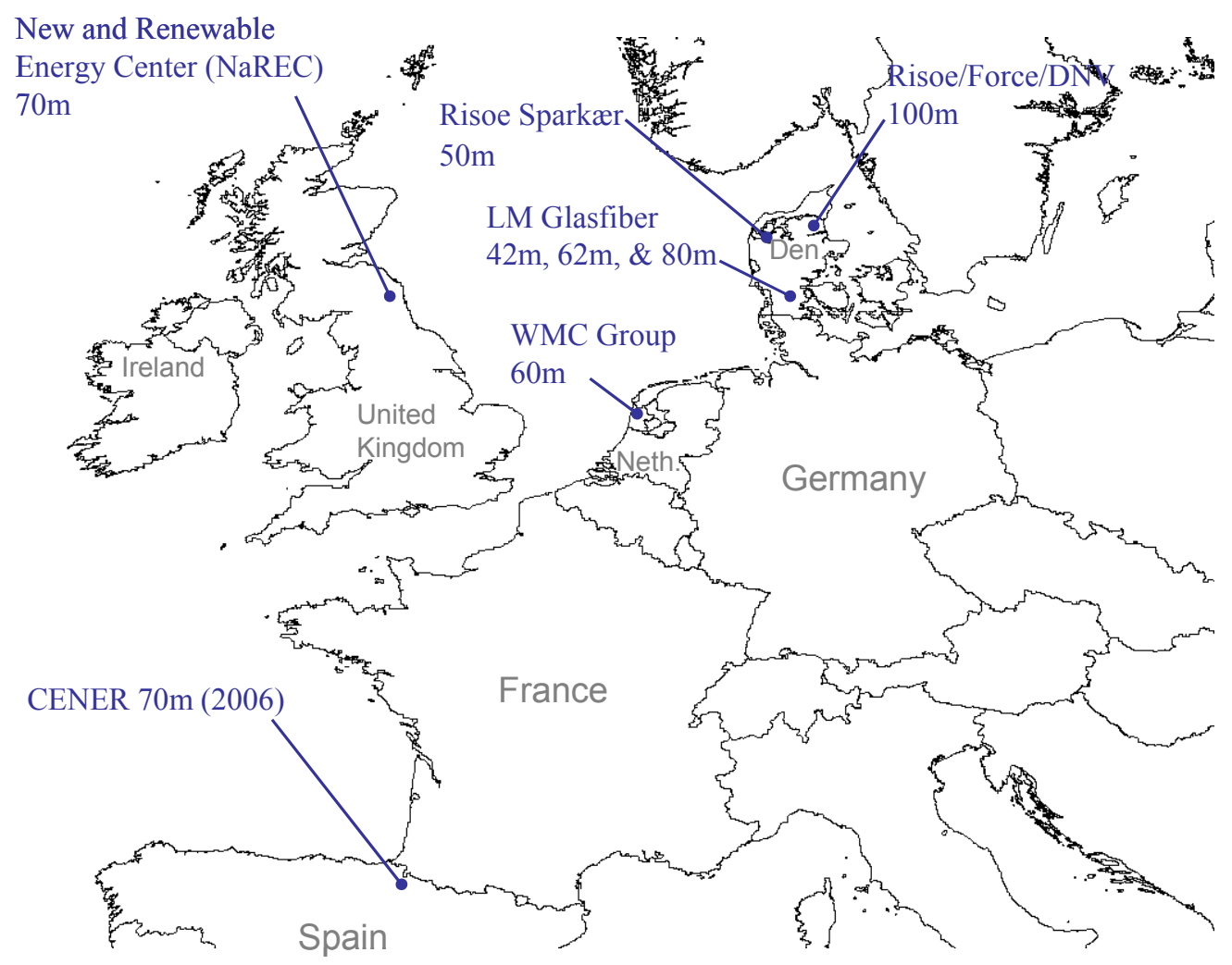

Figure 9: European blade test facility locations and capacities 


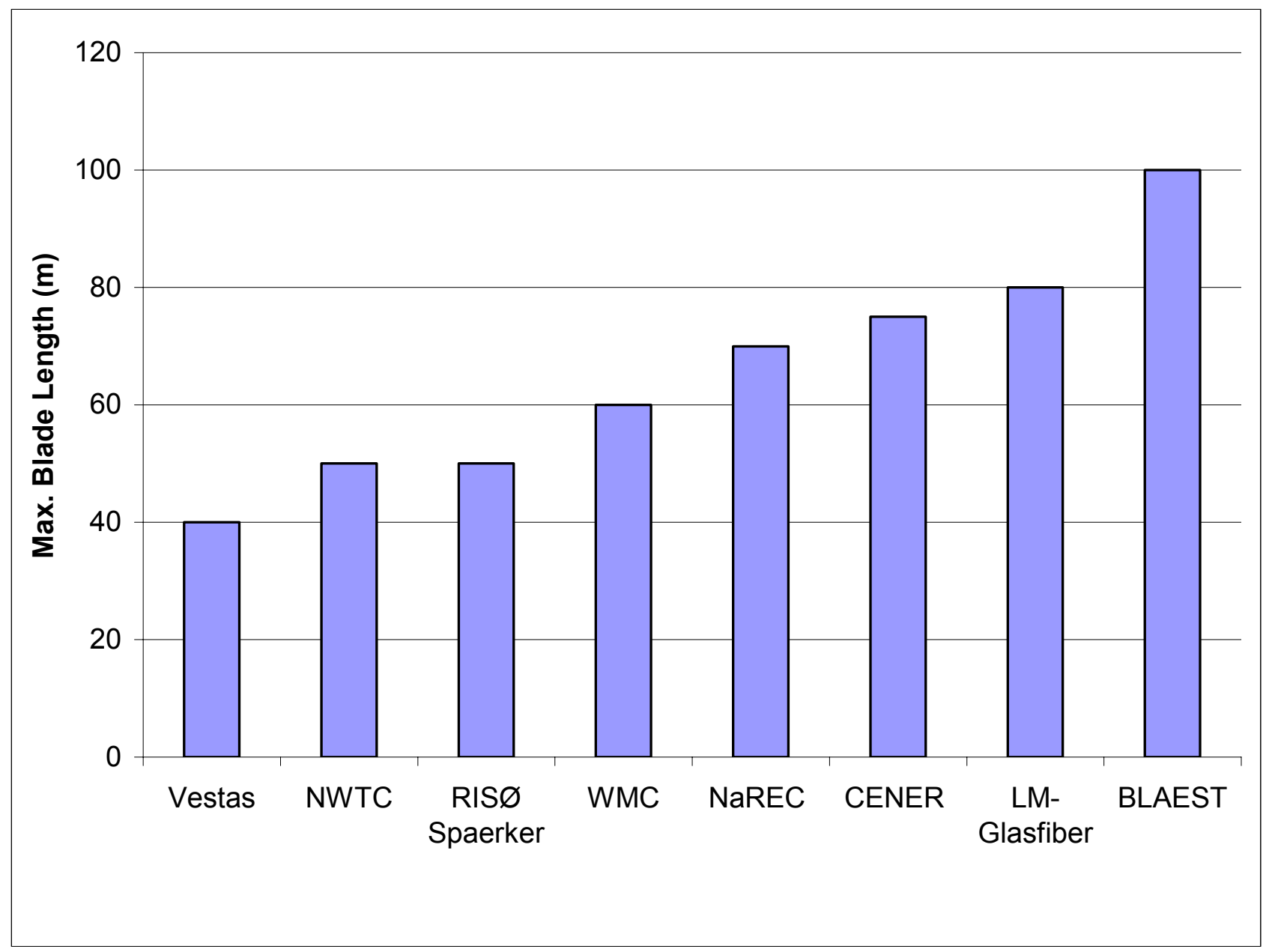

Figure 10: Maximum blade length capacities for blade test facilities worldwide 
Table 7: Overview of European Blade Test Facilities

\begin{tabular}{|c|c|c|c|c|c|c|c|c|}
\hline $\begin{array}{c}\text { Test } \\
\text { Facility }\end{array}$ & Location & $\begin{array}{c}\text { Year } \\
\text { of } \\
\text { Start }\end{array}$ & $\begin{array}{c}\text { Max } \\
\text { Blade } \\
\text { Length } \\
(\mathbf{m}) \\
\end{array}$ & $\begin{array}{c}\text { No. of } \\
\text { Test } \\
\text { Stands }\end{array}$ & $\begin{array}{c}\text { Approx } \\
\text { Test } \\
\text { Bay } \\
\text { Area } \\
\left(\mathbf{m}^{2}\right) \\
\end{array}$ & $\begin{array}{c}\text { Approx } \\
\text { Cost }\end{array}$ & $\begin{array}{l}\text { Approx } \\
\text { Staff }\end{array}$ & Comments \\
\hline RISØ & $\begin{array}{l}\text { Sparkaer } \\
\text { Denmark }\end{array}$ & 1995 & 50 & 5 & 1000 & $\begin{array}{l}\text { Not } \\
\text { Avail. }\end{array}$ & 10 & $\begin{array}{l}\text { Government funded; RIS } \varnothing \text { operated; Danish blades only } \\
\text { www.risoe.dk/rispubl/VEA/sparkaer/sparkaer intro.htm }\end{array}$ \\
\hline $\begin{array}{l}\text { Blade Test } \\
\text { Center } \\
\text { A/S } \\
\text { (BLAEST) }\end{array}$ & $\begin{array}{l}\text { Viborg } \\
\text { Denmark }\end{array}$ & 2005 & 100 & $\begin{array}{l}\text { Not } \\
\text { Avail. }\end{array}$ & $\begin{array}{l}\text { Not } \\
\text { Avail. }\end{array}$ & $\begin{array}{l}\text { Not } \\
\text { Avail. }\end{array}$ & $\begin{array}{l}\text { Not } \\
\text { Avail. }\end{array}$ & $\begin{array}{l}\text { Industry consortium: RISO/Force/DNV } \\
\text { WwW.blaest.com/ }\end{array}$ \\
\hline WMC & $\begin{array}{l}\text { Wieringermeer } \\
\text { Netherlands }\end{array}$ & 2002 & 60 & 2 & 2000 & $\begin{array}{l}\text { Not } \\
\text { Avail. }\end{array}$ & 15 & $\begin{array}{l}\text { TU Delft/ECN enterprise; self-sustaining government start-up } \\
\text { wwW.wmc.tudelft.nl/index.html }\end{array}$ \\
\hline $\begin{array}{l}\text { New and } \\
\text { Renewable } \\
\text { Energy } \\
\text { Center } \\
\text { (NaREC) }\end{array}$ & $\begin{array}{l}\text { Blythe } \\
\text { UK }\end{array}$ & 2005 & 70 & 2 & 1750 & $\$ 5 \mathrm{M}$ & 6 & $\begin{array}{l}\text { UK enterprise; government funded } \\
\text { WwW.narec.co.uk/facilities-blade-test.php }\end{array}$ \\
\hline CENER & $\begin{array}{l}\text { Pamplona } \\
\text { Spain }\end{array}$ & 2006 & 75 & 2 & 2000 & $\begin{array}{l}\text { Not } \\
\text { Avail. }\end{array}$ & $\begin{array}{l}\text { Not } \\
\text { Avail. }\end{array}$ & $\begin{array}{l}\text { New government facility } \\
\text { www.cener.com/cener/?scc }=57 \\
\end{array}$ \\
\hline $\begin{array}{l}\text { LM- } \\
\text { Glasfiber }\end{array}$ & Denmark & 2005 & 80 & 6 & 1200 & $\begin{array}{l}\text { Not } \\
\text { Avail. }\end{array}$ & 9 & $\begin{array}{l}\text { Private; LM blades only } \\
\text { www.lmglasfiber.com/Technology/Test/Fullscale\%20test.aspx }\end{array}$ \\
\hline $\begin{array}{l}\text { Vestas } \\
\text { Blades }\end{array}$ & UK & $\begin{array}{l}\text { Not } \\
\text { Avail. }\end{array}$ & 40 & $\begin{array}{c}\text { Not } \\
\text { Avail. }\end{array}$ & $\begin{array}{c}\text { Not } \\
\text { Avail. }\end{array}$ & $\begin{array}{c}\text { Not } \\
\text { Avail. }\end{array}$ & $\begin{array}{c}\text { Not } \\
\text { Avail. }\end{array}$ & Private test facility; formerly NEG Micon, WEG/Aerolam \\
\hline
\end{tabular}



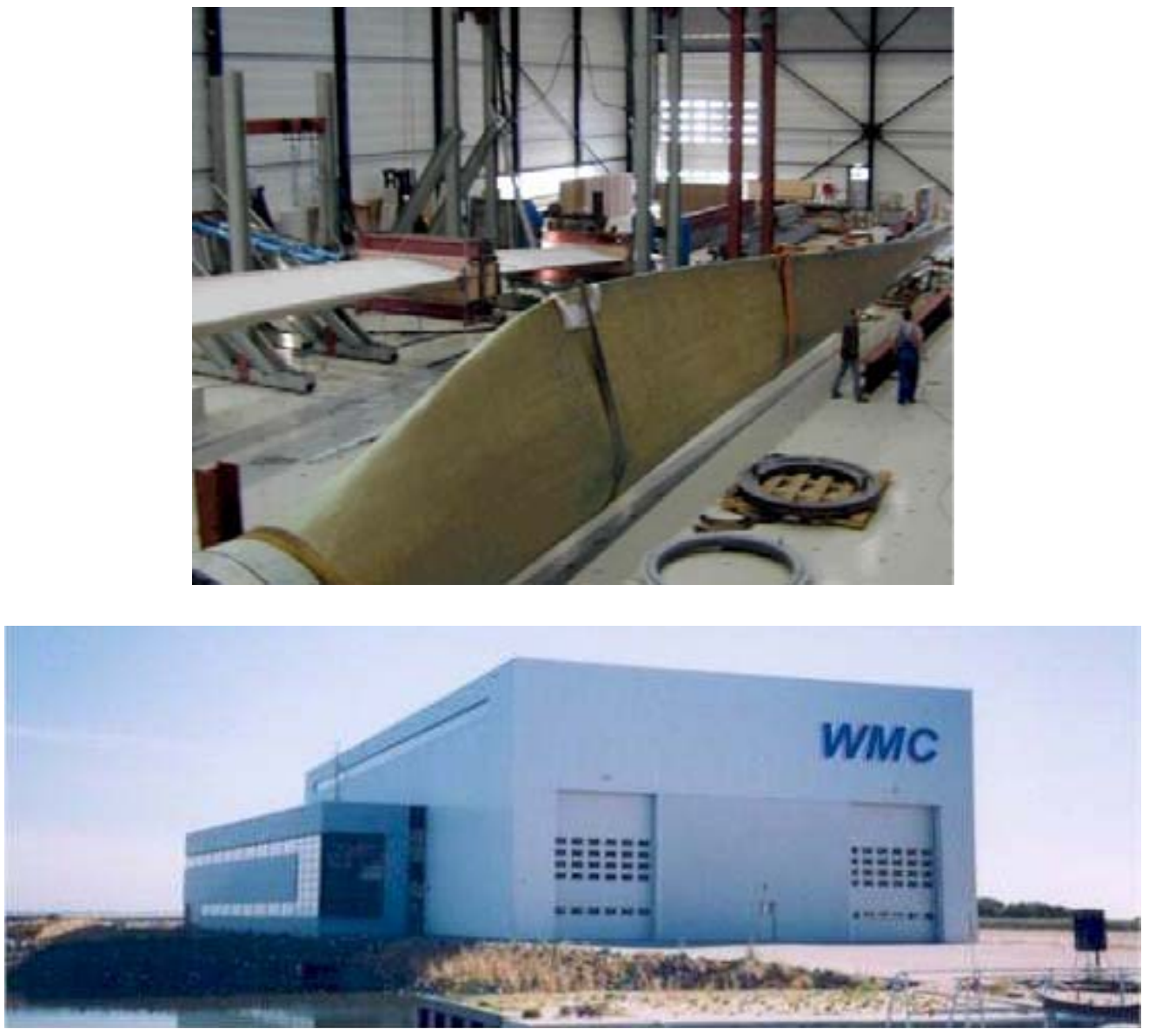

Figure 11: The WMC blade test facility

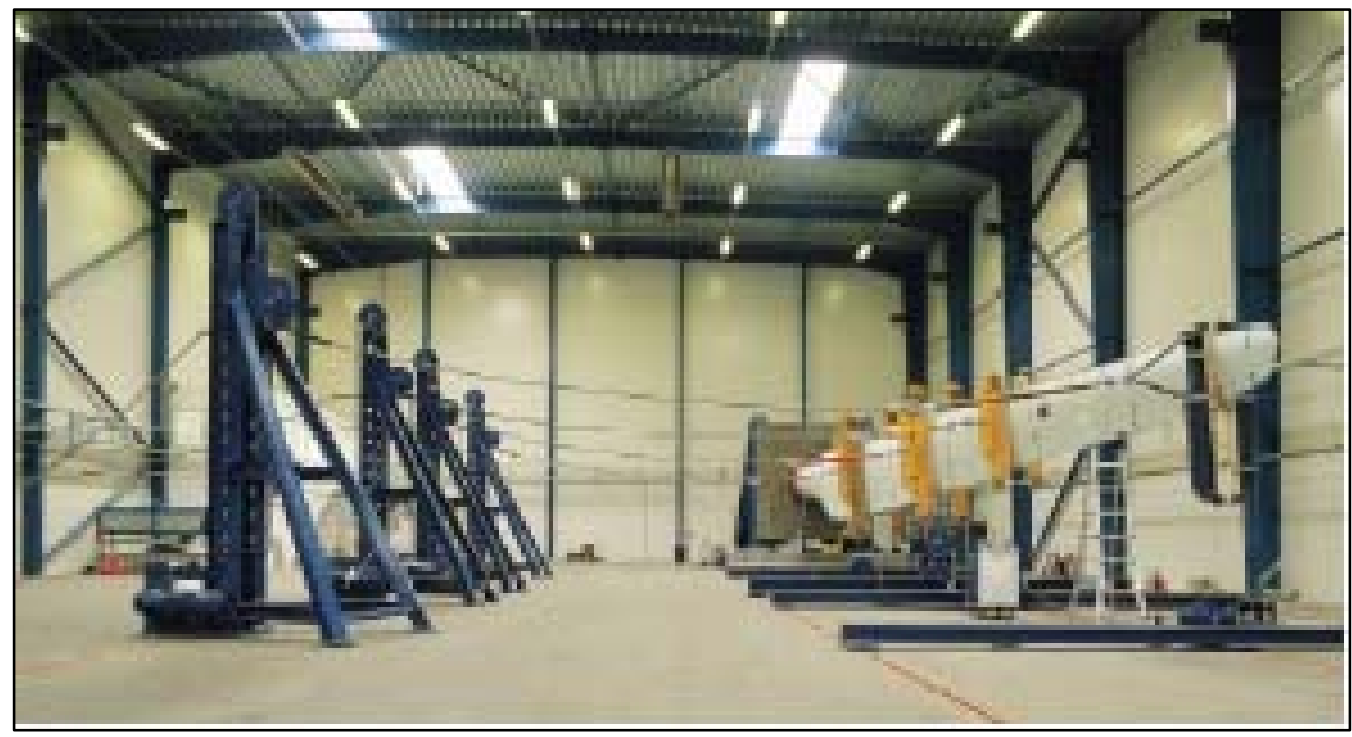

Figure 12: LM Glasfiber blade test facility 

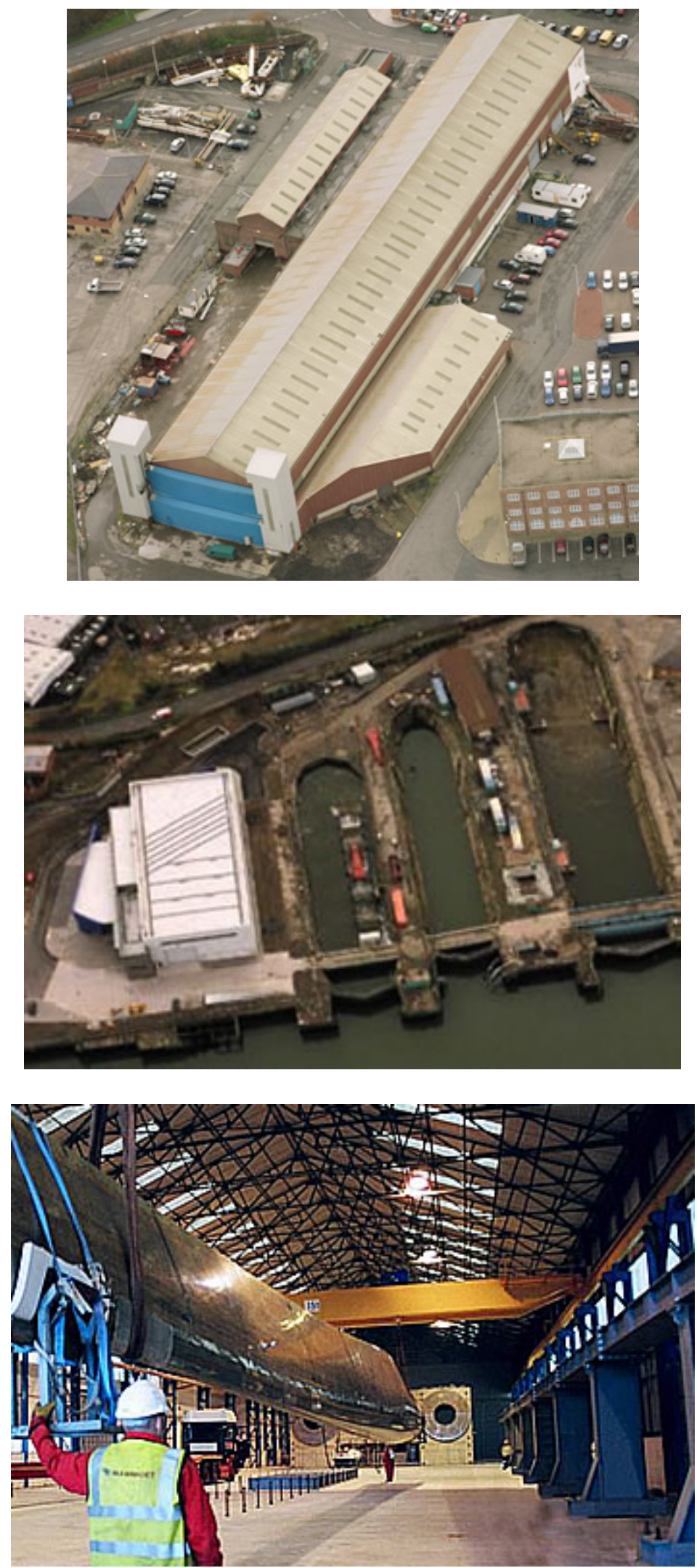

Figure 13: NaREC blade test facility 


\section{Appendix 2: Detailed Requirements for a Large Blade Test Facility}

\section{Table 8: Requirements for a Large Blade Test Facility}

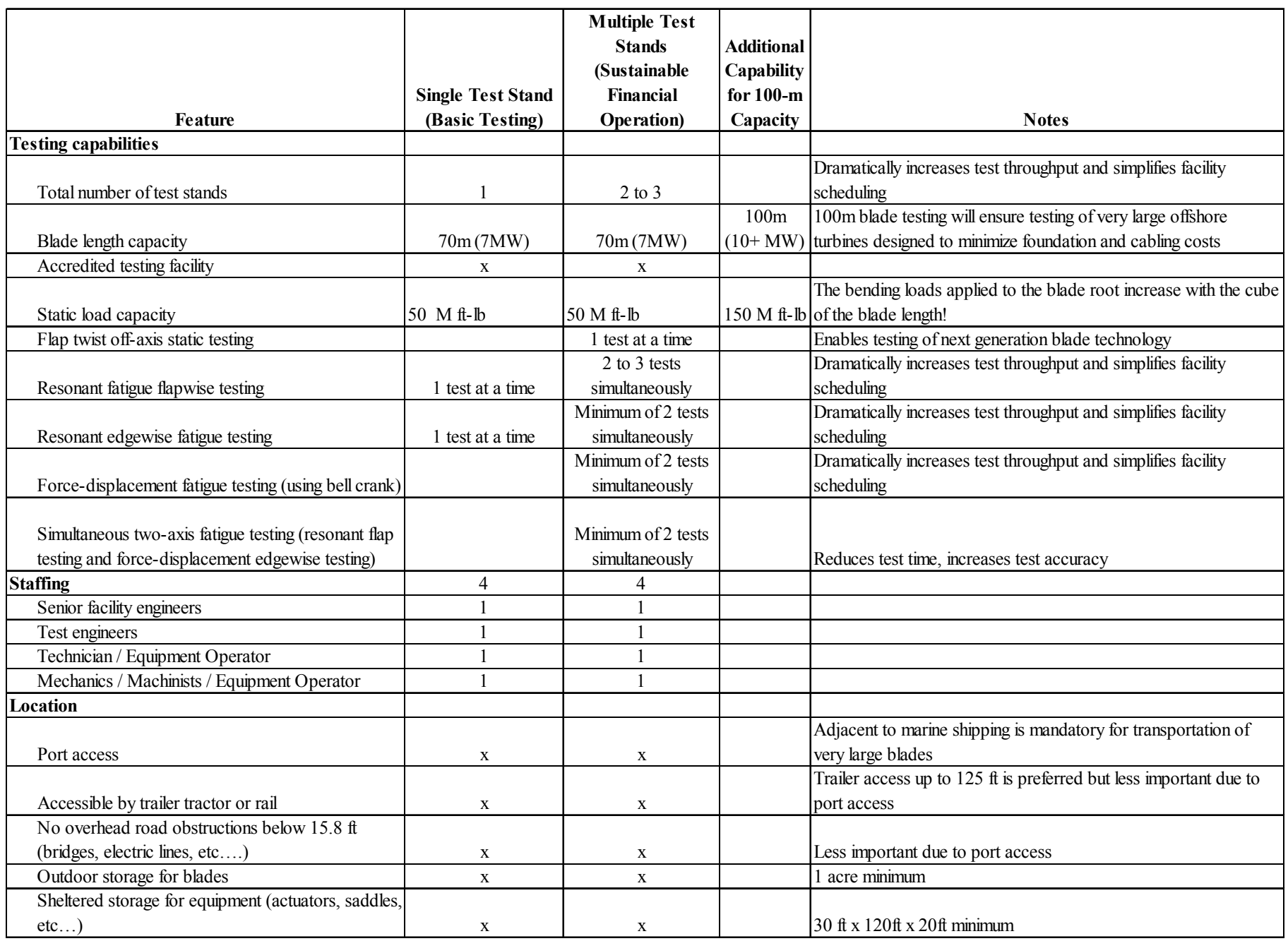




\begin{tabular}{|c|c|c|c|c|}
\hline \multicolumn{5}{|l|}{ Building } \\
\hline Indoor blade prep area & & $\mathrm{x}$ & & $\begin{array}{l}\text { Dramatically increases test throughput and scheduling due to } \\
\text { weather uncertainty }\end{array}$ \\
\hline Total floor space for blade prep and testing & $\begin{array}{l}100^{\prime} \text { wide } 300^{\prime} \\
\text { long } \quad 40^{\prime} \text { tall }\end{array}$ & $\begin{array}{l}150^{\prime} \text { to } 200^{\prime} \text { wide } \\
300^{\prime} \text { long } 50^{\prime} \\
\text { tall }\end{array}$ & $\begin{array}{l}+75^{\prime} \text { wide } \\
+100^{\prime} \text { long } \\
+25^{\prime} \text { tall } \\
\end{array}$ & $\begin{array}{l}\text { Increased width ensures ultimate flap testing capability for the } 70 \mathrm{~m} \\
\text { stands; increased height enables higher load (quicker) fatigue tests } \\
\text { for the } 70 \mathrm{~m} \text { stand; increased height, width, and length are required } \\
\text { to accomadate } 100 \mathrm{~m} \text { blade tests. }\end{array}$ \\
\hline Safety equipment and systems (fire, spills, etc....) & $\mathrm{x}$ & $\mathrm{x}$ & & \\
\hline Control room reinforced for safety & $\mathrm{x}$ & $\mathrm{x}$ & & $20 \mathrm{ft}$ by $30 \mathrm{ft}$ \\
\hline Electrical Service & $\mathrm{x}$ & $\mathrm{x}$ & & $480,1000 \mathrm{~A} \mathrm{~kW}$ \\
\hline Meeting / observation Room & & $\mathrm{x}$ & & Facilitates communication with customers and $\operatorname{staff}(20 \mathrm{ft}$ by $30 \mathrm{ft})$ \\
\hline Office/cubical workspaces & & $\mathrm{x}$ & & 6 standard office cubes $10 \mathrm{ft}$ by $10 \mathrm{ft}$ \\
\hline Machine shop room & $\mathrm{x}$ & $\mathrm{x}$ & & $30 \mathrm{ft}$ by $30 \mathrm{ft}$ \\
\hline Oil pump room & $\mathrm{x}$ & $\mathrm{x}$ & & $30 \mathrm{ft}$ by $30 \mathrm{ft}$ \\
\hline Oil cooling pads - outside w/ containment & $\mathrm{x}$ & $\mathrm{x}$ & & 4 pads $-8 \mathrm{ft}$ by $8 \mathrm{ft}$ each \\
\hline Test stand foundation & $50 \mathrm{M} \mathrm{ft}-\mathrm{lb}$ & $50 \mathrm{M} \mathrm{ft}-\mathrm{lb}$ & $150 \mathrm{M} \mathrm{ft}-\mathrm{lb}$ & $\begin{array}{l}\text { The bending loads applied to the blade root increase with the cube } \\
\text { of the blade length }\end{array}$ \\
\hline Static reaction foundation for side pulls & 200,000 lb@20' & 200,000 lb@20' & $\begin{array}{c}400,000 \mathrm{lb} \\
\text { @ } 22^{\prime}\end{array}$ & Side load increase with the square of the blade length \\
\hline Miscellaneous building load attachment points & \begin{tabular}{|c|}
$\mathrm{x}$ \\
\end{tabular} & \begin{tabular}{|c|}
$\mathrm{x}$ \\
\end{tabular} & & Required for calibrations, equipments anchoring, etc.... \\
\hline \multicolumn{5}{|l|}{ Blade movement \& positioning equipment } \\
\hline Overhead gantry cranes & Two 35 ton & Two 35 ton & Two 70 ton & Cranes span entire test bay \\
\hline Jib crane & 20 ton & 20 ton & 40 ton & \\
\hline Marine travel lift & & 20 ton & 40 ton & Reduces safety risks and damage to test article \\
\hline Fork truck & 7.5 ton & 7.5 ton & 7.5 ton & \\
\hline Blade dolly--Custom designed & 35 ton & 35 ton & 70 ton & $100 \mathrm{~m}$ blade is 2.3 times heavier than $70 \mathrm{~m}$ blade. \\
\hline \multicolumn{5}{|l|}{ Test Hardware } \\
\hline Machine shop equipment and miscellaneous tools & $\mathrm{x}$ & $\mathrm{x}$ & & Lathe, Mill, Saws,.... \\
\hline $\begin{array}{l}\text { Static test equipment ( } 4 \text { winches, cables, \& } \\
\text { saddles) }\end{array}$ & $\begin{array}{l}200,000 \mathrm{lb} \text { total pull } \\
\text { capacity }\end{array}$ & $\begin{array}{l}200,000 \mathrm{lb} \text { total pull } \\
\text { capacity }\end{array}$ & $\begin{array}{c}400,000 \mathrm{lb} \\
\text { total pull } \\
\text { capacity }\end{array}$ & 4 winches \\
\hline Flapwise fatigue exciter and saddles & $\begin{array}{l}4000 \mathrm{lb} \text { oscillating } \\
\text { mass }\end{array}$ & $\begin{array}{l}4000 \mathrm{lb} \text { oscillating } \\
\text { mass }\end{array}$ & $\begin{array}{c}8000 \mathrm{lb} \\
\text { oscillating } \\
\text { mass }\end{array}$ & \\
\hline Bell crank for edgewise fatigue testing & & $100,000 \mathrm{lb}$ & & $\begin{array}{l}\text { Blades longer than } 70 \mathrm{~m} \text { would use untested resonant technology } \\
\text { for edgewise fatigue }\end{array}$ \\
\hline \multicolumn{5}{|l|}{ Hydraulics } \\
\hline Controller & $\mathrm{x}$ & $\mathrm{x}$ & & 1 Flex Test II \\
\hline Pumps & $1 @ 180$ GPM & 2 to $3 @ 180$ GPM & & Model 505; Assumes two-axis fatigue testing \\
\hline 3000-psi piping & $\mathrm{x}$ & $\mathrm{x}$ & & \\
\hline Oil cooling system & $\mathrm{x}$ & $\mathrm{x}$ & & 2 oil-to-air coolers per pump \\
\hline \multicolumn{5}{|l|}{ Instrumentation } \\
\hline Data acquisition & $\mathrm{x}$ & $\mathrm{x}$ & & 64 channels \\
\hline Video & $\mathrm{x}$ & $\mathrm{x}$ & & 2 cameras $w /$ recorders \\
\hline NDE Equipment & & $\mathrm{x}$ & & Blade inspection \\
\hline PCs & 5 & 6 & & \\
\hline
\end{tabular}




\section{Appendix 3: Approximate Costs for Large Blade Test Facility Options}

Table 9: Approximate Capital Costs for Blade Test Facilities

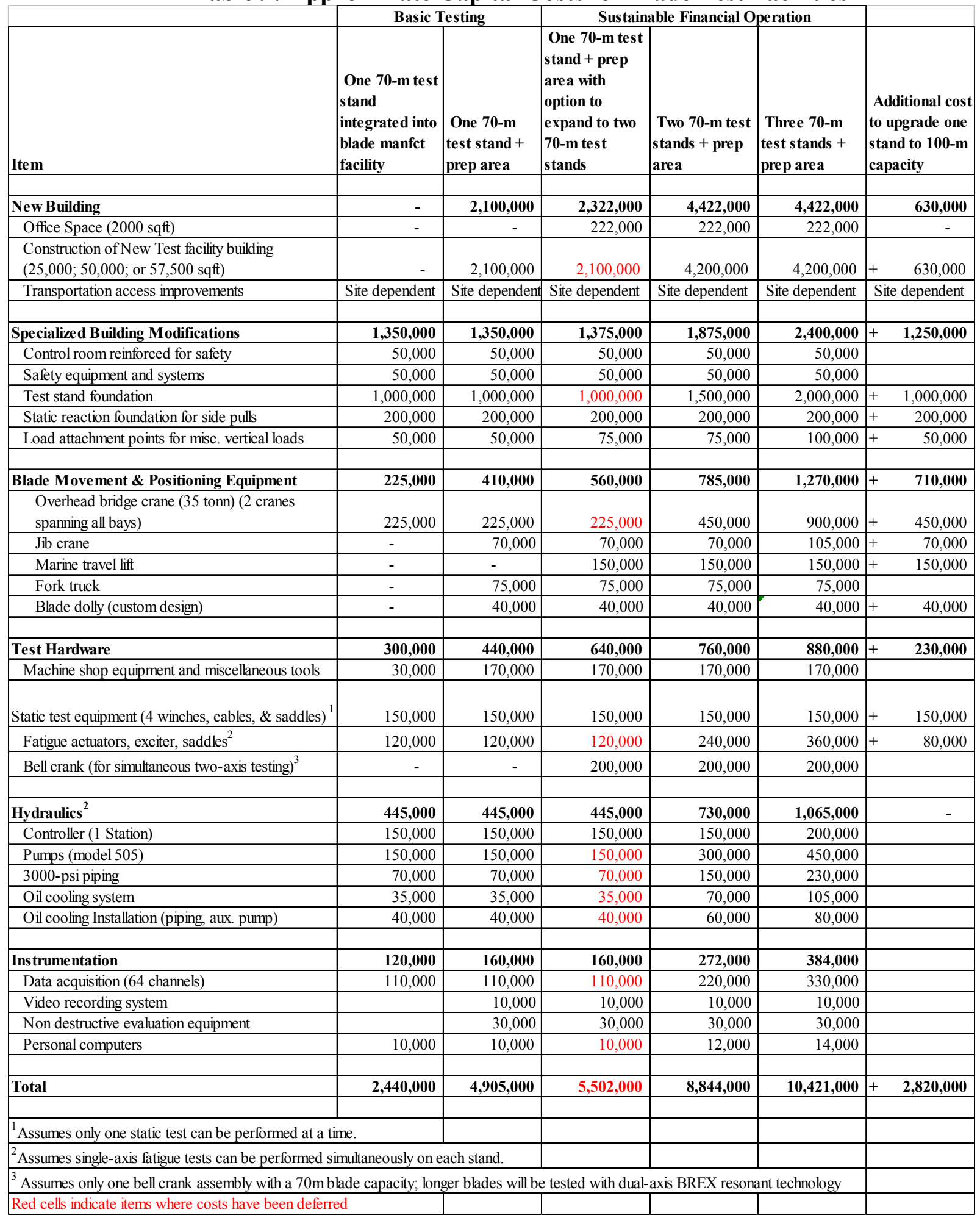




\section{Appendix 4: Approximate Net Revenue for a Large Blade Test Facility}

\section{Table 10: Approximate Revenues from Blade Test Facilities}

\begin{tabular}{|c|c|c|c|c|}
\hline \multicolumn{4}{|c|}{ Fixed Expenses To Operate a Blade Test Facility } & \multirow[b]{2}{*}{$\begin{array}{l}75,000 \text { sqft, three test stand } \\
\text { facility }+2000 \text { sqft office space }\end{array}$} \\
\hline & Cost Load Factor & $\begin{array}{r}25,000 \text { sqft, single test stand } \\
\text { facility }+2000 \text { sqft office space }\end{array}$ & $\begin{array}{c}50,000 \text { sqft, two test stand } \\
\text { facility }+2000 \text { sqft office space }\end{array}$ & \\
\hline & & \begin{tabular}{|l|}
$\begin{array}{l}\text { Approximate yearly cost } \\
\text { (loaded numbers) }\end{array}$ \\
\end{tabular} & \begin{tabular}{|l|}
$\begin{array}{l}\text { Approximate annual cost } \\
\text { (loaded numbers) }\end{array}$ \\
\end{tabular} & $\begin{array}{l}\text { Approximate annual cost } \\
\text { (loaded numbers) }\end{array}$ \\
\hline 4 NREL staff salaries & 2.84 & $\$ \$ 846,022$ & $\$ \$ 846,022$ & $\$ \quad 846,022$ \\
\hline $\begin{array}{l}\text { Capital equipment replacement (for items } \\
\text { over } \$ 50 \mathrm{~K} \text { ) }\end{array}$ & 1.09 & 24,525 & 32,700 & 40,875 \\
\hline $\begin{array}{l}\text { Operating equipment replacement (slings, } \\
\text { computers, load cells) }\end{array}$ & 1.45 & 21,750 & 29,000 & 36,250 \\
\hline $\begin{array}{l}\text { Site equipment maintenance (fuel, repairs, } \\
\text { gov. truck maintenance) }\end{array}$ & 1.00 & 10,000 & 10,000 & 10,000 \\
\hline Site management \& safety & 2.84 & 212,925 & 212,925 & 212,925 \\
\hline Office utilities (less electricity for testing) & 1.00 & 6,000 & 6,000 & 6,000 \\
\hline Office space maintenance & 1.00 & 12,000 & 12,000 & 12,000 \\
\hline $\begin{array}{l}\text { Highbay electricity (less electricity for } \\
\text { hydraulic pumps) }\end{array}$ & 1.00 & 22,500 & 45,000 & 67,500 \\
\hline Highbay heating electricity & 1.00 & 14,040 & 28,080 & 42,120 \\
\hline Insurance & - & . & - & - \\
\hline Building lease & - & - & - & - \\
\hline Subtotal & - & $1,169,762$ & $1,221,727$ & $1,273,692$ \\
\hline $20 \%$ Contingency for unanticipated costs & - & 233,952 & 244,345 & 254,738 \\
\hline Total & - & $1,403,714$ & $1,466,072$ & $1,528,430$ \\
\hline Costs f & or Expendable Materials & for a Full Suite of Tests & & \\
\hline $\begin{array}{l}\text { Two-axis resonant fatigue test, } 70-\mathrm{m} \\
\text { blade, } 34 \text { test days }\end{array}$ & & & & \\
\hline Hydraulic unit electricity & 44,064 & $540 \mathrm{~kW}, 100 \%$ duty cycle & & \\
\hline Cooling circuit pump electricity & 2,754 & $45 \mathrm{~kW}, 75 \%$ duty cycle & & \\
\hline Air/Oil cooler electricity & 2,203 & $36 \mathrm{~kW}, 75 \%$ duty cycle & & \\
\hline Aux electronics electricity & 245 & $\begin{array}{l}\text { 3kW, } 100 \% \text { duty cycle, } \\
\text { estimate }\end{array}$ & & \\
\hline Strain guages & 7,200 & 96 gauges @ \$75 ea. & & \\
\hline Adapter plates \& fasteners \& saddle wood & 25,000 & $20 \mathrm{~K}+2 \mathrm{~K}+2 \mathrm{~K}$ respectively & & \\
\hline Subtotal & 81,466 & & & \\
\hline $\begin{array}{l}\text { Two-axis resonant fatigue test, } 37-\mathrm{m} \\
\text { blade, } 17 \text { test days }\end{array}$ & & & & \\
\hline Hydraulic unit & 9,180 & $225 \mathrm{~kW}, 100 \%$ duty cycle & & \\
\hline Cooling circuit pump & 704 & $23 \mathrm{~kW}, 60 \%$ duty cycle & & \\
\hline Air/Oil cooler & 1,175 & $24 \mathrm{~kW}, 60 \%$ duty cycle & & \\
\hline Aux electronics & 245 & $\begin{array}{l}\text { 3kW, } 100 \% \text { duty cycle, } \\
\text { estimate }\end{array}$ & & \\
\hline Strain guages & 7,200 & 96 gauges @ \$75 ea. & & \\
\hline Adapter plates \& fasteners \& saddle wood & 25,000 & $20 \mathrm{~K}+2 \mathrm{~K}+2 \mathrm{~K}$ respectively & & \\
\hline Subtotal & 43,504 & & & \\
\hline
\end{tabular}




\begin{tabular}{|c|c|c|c|c|}
\hline \multicolumn{5}{|c|}{ Annual Net Revenue for a single test stand facility } \\
\hline & Two $34 \mathrm{~m}$ tests per year & Four $34 \mathrm{~m}$ tests per year & One $70 \mathrm{~m}$ test per year & Three $70 \mathrm{~m}$ tests per year \\
\hline Annual revenue & 600,000 & $1,200,000$ & $1,200,000$ & $\$ \quad 1,800,000$ \\
\hline Expendable materials & $(87,007)$ & $(174,015)$ & $(81,466)$ & $(244,398)$ \\
\hline Facilities fixed expenses & $(1,403,714)$ & $(1,403,714)$ & $(1,403,714)$ & $(1,403,714)$ \\
\hline Net Revenue & $(890,722)$ & $(377,729)$ & $(285,180)$ & 151,888 \\
\hline \multicolumn{5}{|c|}{ Annual Net Revenue for a two test stand facility } \\
\hline & Three $34 \mathrm{~m}$ tests per year & Eight $34 \mathrm{~m}$ tests per year & Two $70 \mathrm{~m}$ tests per year & Six $70 \mathrm{~m}$ tests per year \\
\hline Annual revenue & $\$ 900,000$ & $2,400,000$ & $1,200,000$ & $3,600,000$ \\
\hline Expendable materials & $(130,511)$ & $(348,029)$ & $(162,932)$ & $(488,796)$ \\
\hline Facilities fixed expenses & $(1,466,072)$ & $(1,466,072)$ & $(1,466,072)$ & $(1,466,072)$ \\
\hline Net Revenue & $(696,583)$ & 585,898 & $(429,004)$ & $1,645,132$ \\
\hline \multicolumn{5}{|c|}{ Annual Net Revenue for a three test stand facility } \\
\hline & Three $34 \mathrm{~m}$ tests per year & $1234 \mathrm{~m}$ tests per year & Two $70 \mathrm{~m}$ tests per year & $970 \mathrm{~m}$ tests per year \\
\hline Annual revenue & $\$ 900,000$ & $3,600,000$ & $1,200,000$ & $5,400,000$ \\
\hline Expendable materials & $(130,511)$ & $(522,044)$ & $(162,932)$ & $(733,194)$ \\
\hline Facilities fixed expenses & $(1,528,430)$ & $(1,528,430)$ & $(1,528,430)$ & $(1,528,430)$ \\
\hline Net Revenue & $(758,941)$ & $1,549,526$ & $(491,362)$ & $3,138,376$ \\
\hline \multicolumn{5}{|l|}{ Maximum Net Revenue } \\
\hline & One Test Stand & Two Test Stands & Three Test Stands & \\
\hline Number of $70 \mathrm{~m}$ tests per year & 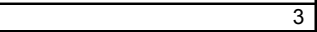 & ( & 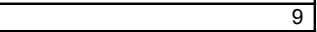 & \\
\hline Annual revenue & $1,800,000$ & $3,600,000$ & $5,400,000$ & \\
\hline Expendable materials & $(244,398)$ & $(488,796)$ & $(733,194)$ & \\
\hline Facilities fixed expenses & $(1,403,714)$ & $(1,466,072)$ & $(1,528,430)$ & \\
\hline Net Revenue & 151,888 & $1,645,132$ & $3,138,376$ & \\
\hline
\end{tabular}




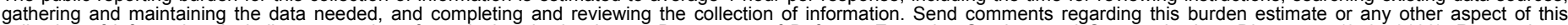

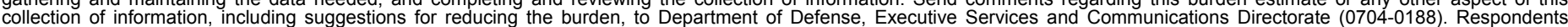

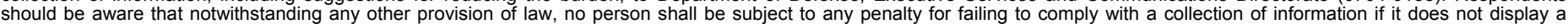

currently valid OMB control number.

PLEASE DO NOT RETURN YOUR FORM TO THE ABOVE ORGANIZATION.
1. REPORT DATE (DD-MM-YYYY) May 2006
4. TITLE AND SUBTITLE
Necessity and Requirements of a Collaborative Effort to Develop a Large Wind Turbine Blade Test Facility in North America

3. DATES COVERED (From - To)

5a. CONTRACT NUMBER

DE-AC36-99-G010337

5b. GRANT NUMBER

5c. PROGRAM ELEMENT NUMBER

5d. PROJECT NUMBER

NREL/TP-500-38044

5e. TASK NUMBER

WER6 3301

5f. WORK UNIT NUMBER
7. PERFORMING ORGANIZATION NAME(S) AND ADDRESS(ES)

National Renewable Energy Laboratory

1617 Cole Blvd.

Golden, CO 80401-3393

\section{PERFORMING ORGANIZATION REPORT NUMBER \\ NREL/TP-500-38044}

9. SPONSORING/MONITORING AGENCY NAME(S) AND ADDRESS(ES)

\section{SPONSOR/MONITOR'S ACRONYM(S)} NREL

11. SPONSORING/MONITORING AGENCY REPORT NUMBER

12. DISTRIBUTION AVAILABILITY STATEMENT

National Technical Information Service

U.S. Department of Commerce

5285 Port Royal Road

Springfield, VA 22161

\section{SUPPLEMENTARY NOTES}

\section{ABSTRACT (Maximum 200 Words)}

The wind power industry in North America has an immediate need for larger blade test facilities to ensure the survival of the industry. Blade testing is necessary to meet certification and investor requirements and is critical to achieving the reliability and blade life needed for the wind turbine industry to succeed. The U.S. Department of Energy's (DOE's) Wind Program is exploring options for collaborating with government, private, or academic entities in a partnership to build larger blade test facilities in North America capable of testing blades up to at least $70 \mathrm{~m}$ in length The National Renewable Energy Laboratory (NREL) prepared this report for DOE to describe the immediate need to pursue larger blade test facilities in North America, categorize the numerous prospective partners for a North American collaboration, and document the requirements for a North American test facility.

\section{SUBJECT TERMS}

wind energy; wind turbines; blades; blade test facility; NWTC; CRADA

\begin{tabular}{|c|c|c|}
\hline $\begin{array}{l}\text { a. REPORT } \\
\text { Unclassified }\end{array}$ & $\begin{array}{l}\text { b. ABSTRACT } \\
\text { Unclassified }\end{array}$ & $\begin{array}{l}\text { c. THIS PAGE } \\
\text { Unclassified }\end{array}$ \\
\hline
\end{tabular}

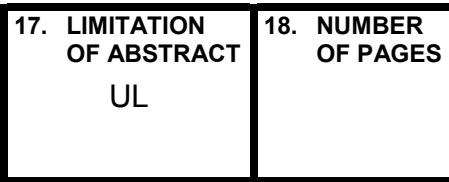

19a. NAME OF RESPONSIBLE PERSON

19b. TELEPHONE NUMBER (Include area code) 